\title{
Mercury and Organic Matter Concentrations in Lake and Stream Sediments in relation to One Another and to Atmospheric Mercury Deposition and Climate Variations across Canada
}

\author{
Mina Nasr and Paul A. Arp \\ Faculty of Forestry and Environment Management, University of New Brunswick, Fredericton, NB, Canada \\ Correspondence should be addressed to Paul A. Arp; arp1@unb.ca
}

Received 17 May 2016; Revised 1 August 2016; Accepted 21 August 2016; Published 3 January 2017

Academic Editor: Stanislav Frančišković-Bilinski

Copyright (C) 2017 M. Nasr and P. A. Arp. This is an open access article distributed under the Creative Commons Attribution License, which permits unrestricted use, distribution, and reproduction in any medium, provided the original work is properly cited.

\begin{abstract}
This article focuses on analyzing the Geological Survey of Canada (GSC) data for total mercury concentrations (THg) in lake and stream sediments. The objective was to quantify how sediment $\mathrm{THg}$ varies by (i) sediment organic matter, determined by loss on ignition (LOI) at $500^{\circ} \mathrm{C}$, (ii) atmospheric $\mathrm{Hg}$ deposition ( $\mathrm{atm} . \mathrm{Hg}_{\mathrm{dep}}$ ) as derived from the Global/Regional Atmospheric Heavy Metals Model GRAHM2005, and (iii) mean annual precipitation and mean monthly July and January temperatures $\left(T_{\text {July }}, T_{\text {Jan }}\right)$. Through regression analyses and averaging by National Topographic System tiles (NTS, 1:250,000 scale), it was found that 40, 70, and $80 \%$ of the sediment THg, LOI, and atm. $\mathrm{Hg}_{\text {dep }}$ variations were, respectively, related to precipitation, $T_{\text {July }}$, and $T_{\text {Jan }}$. In detail, lake sediment $\mathrm{THg}$ was related to atm. $\mathrm{Hg}_{\text {dep }}$ and precipitation, while stream sediment $\mathrm{THg}$ was related to sediment LOI and $T_{\text {July }}$. Plotting sediment THg versus sediment LOI revealed a curvilinear pattern, with highest Hg concentrations at intermediate LOI values. Analysing the resulting 10th and 90th $\log _{10}$ THg percentiles within each $10 \%$ LOI class from 0 to $100 \%$ revealed that (i) atm. $\mathrm{Hg}_{\mathrm{dep}}$ contributed to the organic component of sediment $\mathrm{THg}$ and (ii) this was more pronounced for lakes than for streams.
\end{abstract}

\section{Introduction}

Mercury (Hg) concentrations in lake and stream sediments vary by many factors pertaining to geology, atmospheric $\mathrm{Hg}$ deposition, climate, vegetation, topography, and soil and sediment composition [2-5]. Due to the continuing need to curb anthropogenic Hg emissions, it has become important to determine how these concentrations vary from location to location as influenced by these factors [6]. In general, geogenic contributions to sediment $\mathrm{THg}$ dominate downslope from surface exposed Hg-containing mineral deposits (e.g., [79]). In contrast, atmospheric contributions accrue due to gradual $\mathrm{Hg}$ sequestration by vegetation on land and in water and through subsequent litter production and transport of organic matter by way of surface run-off and sedimentation [10-13]. In detail, the extent of atmospheric $\mathrm{Hg}$ sequestration depends on (i) the rate of atmospheric $\mathrm{Hg}$ deposition [14], (ii) the extent of biological activities and vegetation cover (type, extent, and growth) on land and in water [15-18], (iii) the accumulation of sediment organic matter content [19-21], and (iv) regional to local climate variations as expressed by temperature, precipitation, and length of growing season $[22,23]$.

Once incorporated into organic matter, reevaporation of $\mathrm{Hg}$ is limited by the extent of sunlit surface exposure and biological activity $[24,25]$, with overall turnover times increasing from decades to thousands of years with increasing soil and sediment depth. This extended retention is due to strong Hg-S bonds in the form of organic sulfide groups and S-containing minerals, including HgS such as cinnabar [2628]. Due to decomposition and humification processes, this affinity also leads to a gradual increase of organically bound $\mathrm{Hg}$ concentrations in soils and sediments, as occurs with other elements such as $\mathrm{S}$ and $\mathrm{N}$ [29].

As changes in climate and human activities affect vegetation distributions and growth on land and in water, one would expect that these changes will not only affect the rates of atmospheric $\mathrm{Hg}$ emission and redeposition but would also 
affect the proportioning of organic versus mineral $\mathrm{Hg}$ in soils and sediments. Hence, there are attempts to discern this proportioning through watershed experimentation and isotopic $\mathrm{Hg}$ analyses (e.g., [30, 31]). This article presents how the mineral versus organic proportioning of sediment $\mathrm{Hg}$ can be estimated through cross-referencing geospatial databases that inform about sediment composition, atmospheric $\mathrm{Hg}$ deposition (atm. $\mathrm{Hg}_{\mathrm{dep}}$ ), mean annual precipitation, and mean January and July temperatures $\left(T_{\text {Jan }}, T_{\text {July }}\right)$, with Canada as a case study.

For this study, Canada-wide data layers were available pertaining to $>250,000$ sediment sampling points. The specific objectives were

(i) to determine how the compiled values for lake and stream sediment THg and organic matter within these data layers relate to each other and also to atm. $\mathrm{Hg}_{\text {dep }}$, precipitation, $T_{\text {Jan }}$ and $T_{\text {July }}$ by way of regression analysis;

(ii) to propose a simple model that can be used to determine the extent to which the organic matter contributions to sediment $\mathrm{THg}$ are affected by atm.Hg in particular and precipitation in general.

The working hypothesis was that atmospherically deposited $\mathrm{Hg}$, as sequestered by vegetation, becomes part of soil organic matter through litter fall and biological processing including decay. The extent of this would generally decrease from the temperate forest regions along southeastern Canada and the Pacific coast to the snow-covered barrens and ice fields in the north and in alpine areas.

This article supersedes earlier work on sediment THg distribution as documented by Rasmussen et al. [19] and later by Nasr et al. [3]. That work focused on Canada-wide variations in geogenic $\mathrm{Hg}$ sources and how sediment $\mathrm{THg}$ varies topographically from uplands to lowlands, with sediment THg being higher in upland than lowland sediments, and generally decreasing with stream order and successive wetland and lake retention of upland-generated sediment contributions. The latter was revealed through case studies centered on the Selwyn Basin in the Yukon Territory, where surface exposure of black shales generates stream sediments with high $\mathrm{THg}$ concentrations while downstream sediment $\mathrm{THg}$ concentrations decrease with increasing upslope flow accumulation areas [3]. Further case studies similar to this can be found in Nasr [32] for Nova Scotia, Quebec, and Bathurst Island (Nunavut). The advances to be described in this article refer to

(i) using a nearly doubled database for sediment $\mathrm{THg}$ and sediment organic matter as determined by loss on ignition at $500^{\circ} \mathrm{C}$ (LOI) by including the sediment data for Quebec and Nova Scotia;

(ii) relating sediment $\mathrm{THg}$ and LOI to the atmospheric deposition and climate variations across Canada;

(iii) determining how the mineral to organic contributions to sediment vary as LOI increases from 0 to $100 \%$ within the context of increasing atmospheric $\mathrm{Hg}$ deposition loads.
Linear and nonlinear regression analyses were used to evaluate

(i) the general trends regarding sediment $\mathrm{THg}$, sediment LOI in reference to the Canada-wide variations in atmTHg $g_{\text {dep }}$ versus precipitation, $T_{\text {Jan }}$, and $T_{\text {July }}$;

(ii) how the mineral and organic portions of sediment $\mathrm{THg}$ can, at least in part, be quantified in terms of the following model:

$$
\begin{aligned}
\log _{10} \mathrm{THg}_{i, j}\left(\operatorname{ngg}^{-1}\right)= & a_{i j}\left(1-\frac{\mathrm{LOI}(\%)}{100}\right) \\
& +b_{i j}\left[1-\exp \left(-c_{j} \text { LOI }(\%)\right)\right],
\end{aligned}
$$

where " $j=1$ " and " $j=2$ " refer to lakes and streams, " $i$ " refers to provinces, territories, and geological survey zones in Quebec, and $a_{i j}, b_{i j}$, and $c_{j}$ are the corresponding regression coefficients. With this model, it is assumed that

(i) the mineral component of sediment $\mathrm{THg}$ is set to decrease from $a_{i j}$ to $0 \%$ as organic matter increases from 0 to $100 \%$;

(ii) the organic component of sediment $\mathrm{THg}$ is set to increase asymptotically as LOI increases from 0 towards $b_{i j}\left[1-\exp \left(-c_{j}\right.\right.$ LOI $\left.\left.(\%)\right)\right]$ as an upper limit when LOI $=100 \%$, that is, similar to THg versus LOI summarized by Munthe et al. [33]; essentially, organic matter contributions to sediment $\mathrm{THg}$ weaken somewhat with increasing organic matter because the weight ratio between $\mathrm{THg}$ and organic matter can be expected to decrease on account of (i) growth dilution, whereby the rate of $\mathrm{Hg}$ availability is constant but the rate of organic matter accumulation varies from being low to high, and (ii) increased loss of oxidized $\mathrm{Hg}$ from water-saturated organic soils and sediments due to enhanced rates of bio-chemical $\mathrm{Hg}(0)$ evasion [34-36]; parallel to this is the decreasing $\mathrm{THg}$ to dissolved organic matter concentration ratio as dissolved organic matter concentrations in stream and lake waters increase from low to high [37];

(iii) as a result, the sediment $\mathrm{THg}$ versus LOI profile should reach a maximum value at intermediate LOI values as determined by the relative strength of the mineral versus the organic sediment $\mathrm{THg}$ contributions;

(iv) the $c_{j}$ coefficient by which the organic component of $\mathrm{Hg}$ increases to an asymptotic value with increasing LOI is, as a simplification, set not to vary in principle from location to location, but may differ from streams to lakes.

The resulting best-fitted linear and nonlinear regression models are subsequently used to model and map lake and stream sediment THg and LOI, with Canada-wide rasters for atmTHg $\mathrm{dep}_{\text {dep }}$, precipitation, $T_{\text {Jan }}$, and $T_{\text {July }}$ as predictor variables. 


\section{Methods}

2.1. Data Compilation. Bulk lake and stream sediment concentration data for THg and LOI were obtained from the open geochemical survey files of Natural Resources Canada, Government of Quebec, and Province of Nova Scotia [38]. The procedures used for generating these data followed a standard protocol for sampling, sample preparation, and laboratory analysis [39]. Lake sampling involved retrieving $30 \mathrm{~cm}$ deep sediment cores, with muddy tops removed. Stream samples were collected from active channels. Samples were collected and analyzed from region to region from 1960 onward to 2008. The files contained the following information:

(i) the geographic location: longitude, latitude, National Topographic System (NTS) map tile number of each lake and stream sampling location;

(ii) water and sediment characteristics of the sampled streams and lakes, notably lake area and depth, stream channel width, and depth, stream order and flow rate, water, and sediment colour;

(iii) terrain type and landform;

(iv) elemental composition, approximately 36 elements including heavy metals, notably $\mathrm{Hg}, \mathrm{Cu}, \mathrm{Zn}, \mathrm{Pb}, \mathrm{Cd}$, As, and Au and other elements such as Fe, Mn, Se, and $\mathrm{S}$ (however, Se and $\mathrm{S}$ data were sparse);

(v) LOI at $500^{\circ} \mathrm{C}[26]$.

The open files were compiled as part of an ArcMap project, with 235,943 sampling points containing data for both sediment $\mathrm{THg}$ and LOI. For the cross-referencing purposes, the THg and LOI entries were supplemented with point-extracted values from the following Canada-wide data layers [32]:

(i) Bedrock geology polygon shapefile, including rock type, age, formation, and faults [40, 41].

(ii) Ecological land classification (vegetation/land cover) and terrestrial and ecological ecozone; [42].

(iii) The cover types classified as snow/ice (glacial, nonglacial), sparse vegetation, barren (bare ground with no vegetation), frost worked-soil (cryptogam crust, frost boils with sparse graminoids and cryptogam plants), tundra (graminoid, shrub), wetlands (bog, fen, swa$\mathrm{mp}$, and marsh), and forest (broadleaf, conifer, mixed wood).

(iv) Mean annual net atmospheric $\mathrm{Hg}$ deposition rate (Global/Regional Atmospheric Heavy Metals Model; GRAHM2005 atm.Hg $\mathrm{g}_{\mathrm{dep}}, \mu \mathrm{g} \mathrm{m}^{-2} \mathrm{a}^{-1}$; [14]), a raster grid with a $25 \times 25 \mathrm{~km}^{2}$ grid resolution (Figure 1(a)).

(v) The 1961-1990 rasters ( $4 \mathrm{~km}^{2}$ grids) for mean annual precipitation rate (precipitation, $\mathrm{m} \mathrm{a}^{-1}$ ) and July and January air temperatures $\left(T_{\text {July }}, T_{\text {Jan }} ;{ }^{\circ} \mathrm{C}\right)$, all generated with the "Parameter-elevation Regressions on Independent Slopes Model” (PRISM [43]: Figures 1(b), $1(\mathrm{c})$ and $1(\mathrm{~d})$ ).

(vi) Digital elevation models in raster format:
(a) National Digital Elevation Model (DEM) grid at $300 \mathrm{~m}$ [44].
(b) Canadian National Topographical Database at 30 m (NTDB: YT [45]).
(c) Enhanced DEM at $20 \mathrm{~m}$ (2006; NS [46]).
(d) Shuttle Radar Topography Mission (SRTM: NU, QC, NWT) at $90 \mathrm{~m}$ resolution.

The resulting raster-extracted shapefile for the Hg survey points was exported as a text file for further processing, to enable data quality control, statistical analyses, and plotting, using Excel, Statview, and ModelMaker software. Quality assurance involved inspecting the compiled data and correcting for

(i) faulty data alignments within and across individual files;

(ii) numerical and typographical inconsistencies within each column;

(iii) identifying, eliminating, and/or correcting data entries with typographical error, misspellings, order of magnitude outliers, and faulty locations: the GSC referenced longitude and latitude locations had to fall along already mapped or DEM-derived water courses and open surface water features (lakes).

2.2. Statistical Procedures. The statistical analyses were done by province and territory (all of Canada) and by Quebec survey zone (Figure 12) to produce

(i) basic summary tables, by provinces/territories and Quebec survey zones and by NTS tiles;

(ii) scatterplots of $\log _{10} \mathrm{THg}$ versus LOI by lakes and streams;

(iii) $\log _{10} \mathrm{THg}$ and LOI frequency distributions;

(iv) the best-fitted linear regression results for GRAHM2005-generated atm. $\mathrm{Hg}_{\text {dep }}$, sediment $\mathrm{THg}$ and sediment LOI using the PRISM rasters for precipitation, $T_{\text {Jan }}$ and $T_{\text {July }}$ as predictor variables ((3) to (6));

(v) 10th, 25th, 50th, 75th, and 90th percentile summaries of $\log _{10} \mathrm{THg}$ for each $10 \%$ LOI class from 0 to $100 \%$, all split by provinces/territories and by geological survey zones in Quebec;

(vi) the best-fitted nonlinear regression results for the $a_{i j}$, $b_{i j}$, and $c_{j}$ coefficients of (1) based on the plots of the 10 th and 90 th percentiles of $\log _{10} \mathrm{THg}$ per each $10 \%$ LOI class;

(vii) the best-fitted trends of $b_{i j}$ versus atm. $\mathrm{Hg}_{\text {dep }}$ and precipitation.

The regression analysis results were reported by compiling the least-squares fitted intercepts (if applicable), the regression coefficients, their standard errors of estimates, and corresponding $t$ and $p$ values. Variables with significant influence were selected as part of the stepwise procedure when (i) $t$-values were $>4.0$, (ii) $p$-values $<0.001$, (iii) $\mathrm{THg}$ 


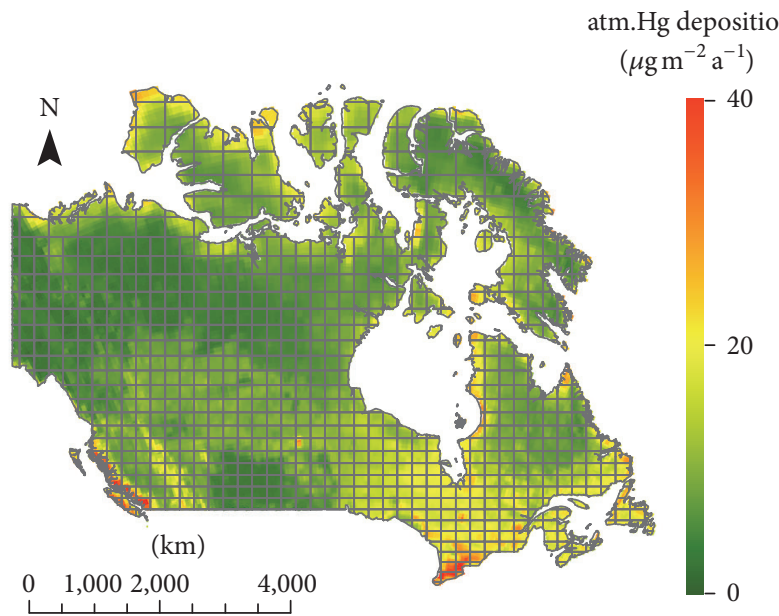

(a)

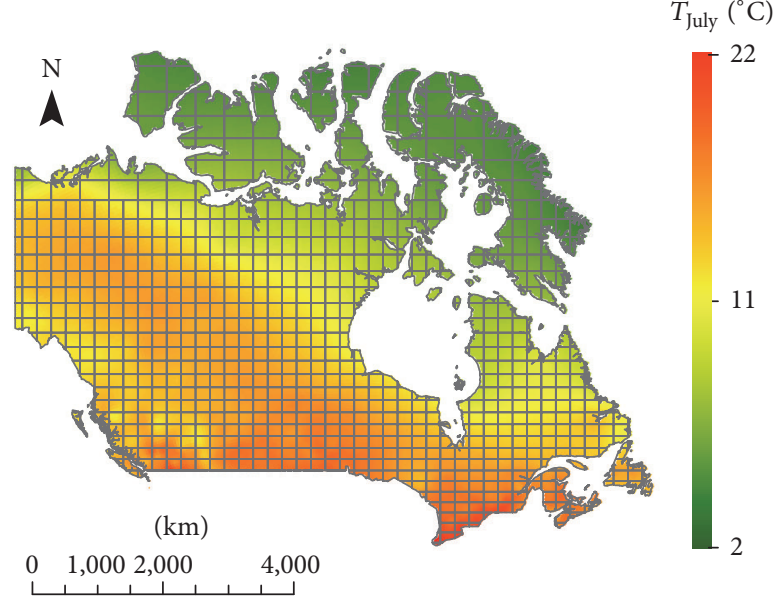

(c)

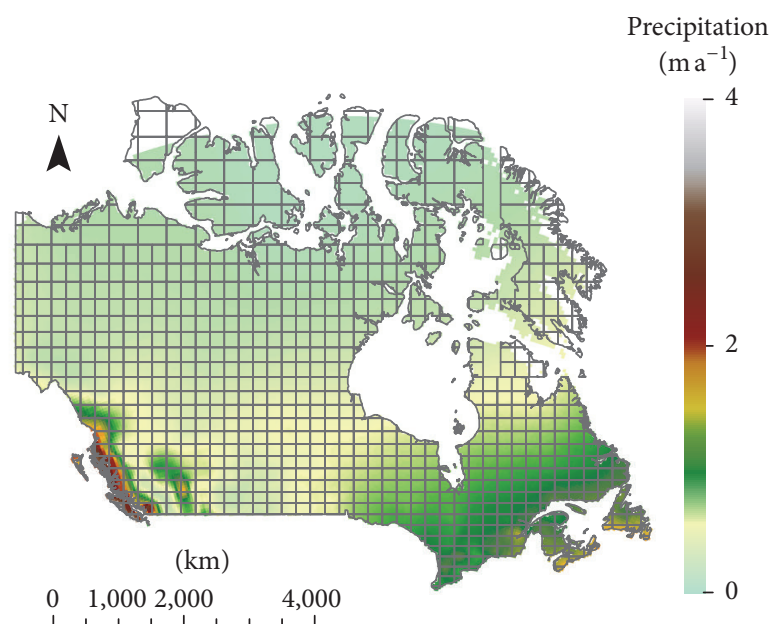

(b)

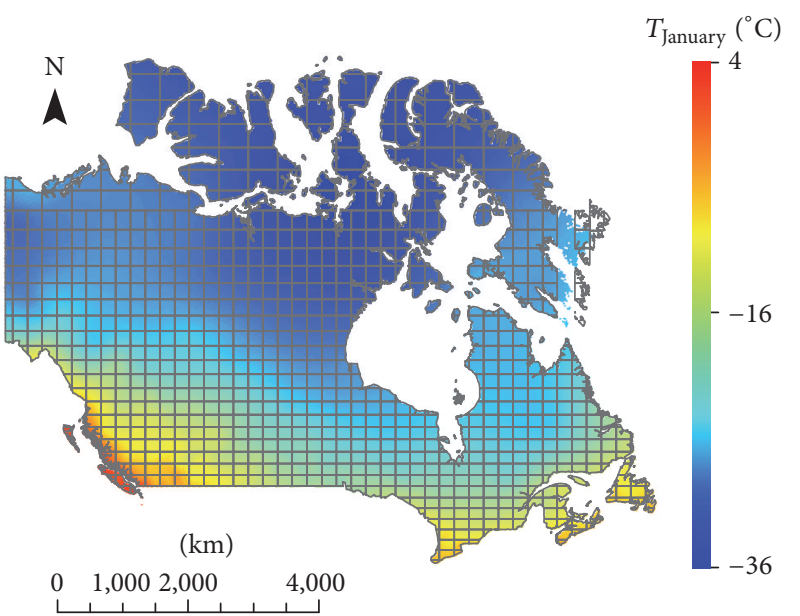

(d)

FIGURE 1: Canada-wide projections for atmospheric Hg deposition, mean annual precipitation, and mean annual July and January temperatures, overlaid by the $1: 250,000$ National Topographic System tile pattern.

and LOI values remained positive, (iv) geographic location variables improved the best-fitted results significantly, and (v) choosing the most significant variable among partially correlated variables. Progress towards the best-fitted results was monitored by examining the actual versus best-fitted scatterplots at each step for the purpose of increasing the linearity between actual and best-fitted values while obtaining even (heteroscedastic) scatterplot distributions. Doing this included variable transformations, for example, THg to $\log _{10} \mathrm{THg}$, precipitation to precipitation ${ }^{0.5}$, LOI to $\log _{10} \mathrm{LOI}$, and redoing the analyses.

2.3. Mapping Procedures. The best-fitted linear regression models were used to map lake and stream sediment $\mathrm{THg}$ and LOI across Canada, using the Canada-wide rasters for atm. $\mathrm{Hg}_{\text {dep }}$, precipitation, $T_{\text {Jan }}$, and $T_{\text {July }}$ as predictive layers. This also included mapping the gain in sediment THg with increasing LOI using the following formulation:

$$
\log _{10}(\text { THg Gain })=b_{i j}(x)\left[1-\exp \left(-c_{j} \text { LOI }(\%)\right)\right]
$$

with " $x$ " referring to NTS-averaged values for atm. $\mathrm{Hg}_{\text {dep }}$ or precipitation.

\section{Results and Discussion}

3.1. Sediment THg and LOI Data Presentation. The overview in Figure 2 identifies the extent and variations of sediment THg across Canada, by lake and stream sampling locations, which most frequently but not exclusively focused on western and eastern Canada, respectively. High to very high $\mathrm{THg}$ concentrations are generally associated with bedrock formations with mineral $\mathrm{Hg}$ exposures, such that they occur within the Selwyn Basin of the Yukon Territory [47] and in combination with sulfide mineral exposures due tectonic uplift (e.g., British Columbia [48-50]; Nova Scotia [51]; Quebec [52, 53]), rift (Labrador Trough, [54]), mafic volcanic extrusions (Quebec [55]; Labrador [56]), and meteor impacts (Sudbury, Ontario [57]). Some of the THg anomalies are associated with sedimentary formations, especially where these are overlaying intruding or extruding formation or 


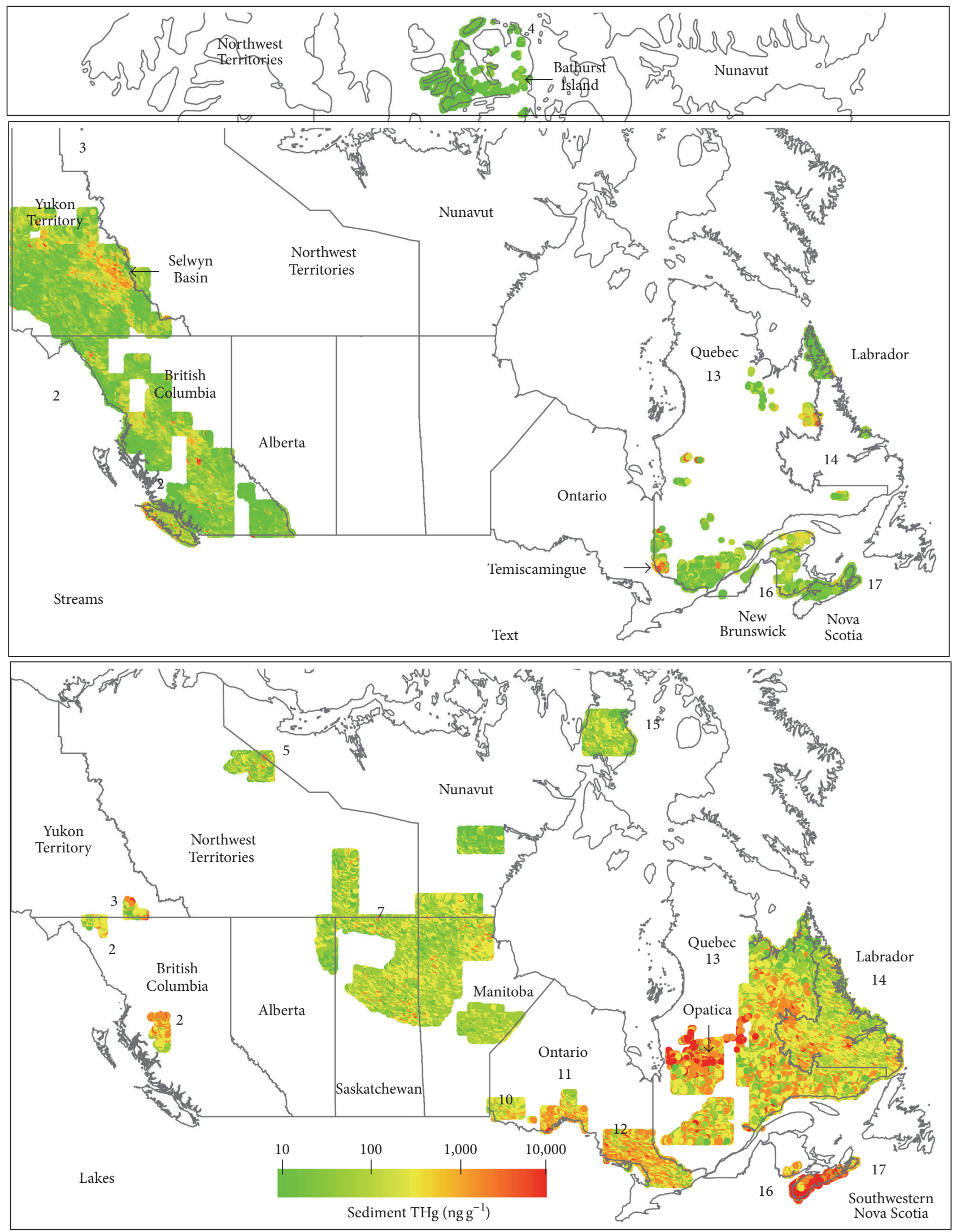

FIGURE 2: Point-by-point THg concentrations ( $\mathrm{ng} \mathrm{g}^{-1}, \log _{10}$ scale) in lake and stream sediments across Canada, as found in the open files of the Geological Survey of Canada, Quebec, and Nova Scotia. For data summary by provinces/territories and by survey zones in Quebec, see Tables 2 and 3, respectively. 
TABLE 1: Mean sediment THg and LOI for streams and lake, by provinces and territories.

\begin{tabular}{|c|c|c|c|c|c|c|c|c|c|c|}
\hline \multirow{2}{*}{ Province/territories } & \multirow{2}{*}{ Medium } & \multirow{2}{*}{$n$} & \multicolumn{4}{|c|}{ Sediment THg $\left(\mathrm{ng} \mathrm{g}^{-1}\right)$} & \multicolumn{4}{|c|}{ Sediment LOI (\%) } \\
\hline & & & Mean & Min. & Max. & Std. Dev. & Mean & Min. & Max. & Std. Dev. \\
\hline $\mathrm{AB}$ & \multirow{13}{*}{ Lakes } & 1,147 & 35.7 & 5 & 367 & 19.0 & 49.3 & 1.3 & 94.7 & 22.2 \\
\hline $\mathrm{BC}$ & & 551 & 106.7 & 10 & 960 & 71.3 & 31.8 & 1.6 & 88.2 & 18.0 \\
\hline $\mathrm{MN}$ & & 17,970 & 51.6 & 8 & 960 & 26.2 & 40.1 & 1.0 & 99.8 & 22.6 \\
\hline NB & & 335 & 129.1 & 25 & 270 & 43.2 & 39.2 & 4.4 & 95.8 & 14.1 \\
\hline NL & & 19,290 & 84.9 & 8 & 900 & 57.3 & 27.7 & 0.8 & 98.5 & 14.3 \\
\hline NS & & 3,753 & 367.9 & 10 & 6,940 & 356.6 & 38.7 & 0.5 & 97.6 & 16.6 \\
\hline NU & & 5,810 & 46.4 & 10 & 200 & 25.6 & 22.6 & 1.0 & 91.6 & 18.3 \\
\hline NWT & & 4,063 & 51.3 & 10 & 525 & 32.2 & 34.6 & 1.0 & 94.3 & 20.7 \\
\hline $\mathrm{ON}$ & & 14,130 & 119.7 & 10 & 21,000 & 196.2 & 40.3 & 1.0 & 98.8 & 19.0 \\
\hline QC & & 56,598 & 127.5 & 5 & 9,820 & 154.5 & 28.0 & 1.0 & 98.0 & 19.2 \\
\hline SK & & 12,142 & 57.9 & 6 & 1,560 & 40.1 & 35.1 & 0.5 & 96.4 & 17.5 \\
\hline YT & & 204 & 85.1 & 6 & 720 & 83.6 & 41.7 & 5.0 & 88.7 & 16.9 \\
\hline Total & & 135,993 & 104.4 & 5 & 21,000 & 61.9 & 32.0 & 0.5 & 99.8 & 18.7 \\
\hline $\mathrm{BC}$ & \multirow{8}{*}{ Streams } & 16,679 & 83.6 & 10 & 22,690 & 445.9 & 8.6 & 0.1 & 92.4 & 8.7 \\
\hline NB & & 7,413 & 81.6 & 10 & 6,830 & 98.6 & 17.9 & 1.0 & 96.4 & 13.8 \\
\hline NL & & 1,142 & 33.1 & 10 & 410 & 31.2 & 8.8 & 1.0 & 78.4 & 8.9 \\
\hline $\mathrm{NU}$ & & 403 & 25.4 & 10 & 170 & 16.4 & 7.7 & 0.4 & 42.2 & 7.3 \\
\hline NWT & & 447 & 111.5 & 30 & 727 & 93.5 & 8.5 & 0.8 & 52.5 & 6.7 \\
\hline QC & & 19,797 & 162.9 & 5 & 9,392 & 309.9 & 18.0 & 1.0 & 100.0 & 19.2 \\
\hline YT & & 19,487 & 73.1 & 5 & 4,350 & 119.7 & 9.0 & 0.4 & 100.0 & 9.3 \\
\hline Total & & 65,368 & 103.2 & 5 & 22,690 & 228.1 & 12.6 & 0.1 & 100.0 & 12.7 \\
\hline Total & & 201,361 & 104.0 & 5 & 22,690 & 159.0 & 25.7 & 0.1 & 100.0 & 16.8 \\
\hline
\end{tabular}

Calculated weighted mean and standard deviation (Std. Dev.) for locations with both THg and LOI values.

where they are enriched with organic matter as in black shales or coal seams. Other anomalies refer to the accumulation of sediment $\mathrm{Hg}$ due to past and current mining activities and gold extraction activities in particular (see, e.g., [58]).

The dependence of sediment $\log _{10} \mathrm{THg}$ versus sediment LOI followed curvilinear patterns (Figures 3 and 4), as to be quantified by way of (1) and as discussed by Rasmussen et al. $[19,20]$. These plots are, however, generally less curved for lakes than for streams. In addition, some of stream plots have high THg values at low LOI and notably so for British Columbia, Yukon Territory, and some of the Quebec survey zones with high surface exposures of $\mathrm{Hg}$-containing minerals. For the Grenville zones (zones 23 to 26, Figure 12) there is a clear separation of high to low stream sediment $\mathrm{THg}$ due to regional differences between high and low upslope $\mathrm{Hg}$ exposures.

Tables 1 and 2 summarize sediment THg and LOI by provinces/territories and by Quebec survey zones. These entries indicate that, on average, lowest THg values occur in Nunavut and Labrador streams. Also, on average, lake sediment THg is highest for southwestern Nova Scotia, while stream sediment THg is highest for (i) the Temiscamingue survey zone (Grenville zone 23) in Quebec, mainly due to exposure of mafic volcanic bedrock exposures and (ii) across the black shale formations of the Selwyn Basin within the Yukon Territory (Figure 2).
3.2. Relationships between $\mathrm{THg}, \mathrm{LOI}$, atm. $\mathrm{Hg}_{\text {dep }}$, Precipitation, $T_{\text {July }}$, and $T_{\text {Jan }}$. The linear regression analyses pertaining to the NTS-tile averaged values for atmospheric $\mathrm{Hg}$ deposition as well as sediment $\mathrm{Hg}$ and sediment LOI all revealed a strong dependence on the Canada-wide climate variations, as quantified by the following best-fitted regression equations, with fairly evenly distributed actual versus best-fitted and fairly evenly distributed scatterplots in Figure 6:

$$
\begin{aligned}
\text { atm. } & H_{\text {dep }}\left(\mu \mathrm{g} \mathrm{m}^{-2} \mathrm{a}^{-1}\right) \\
= & (-24.7 \pm 0.8) \\
& +(26.8 \pm 1.0)\left[\text { Precipitation }\left(\mathrm{m} \mathrm{a}^{-1}\right)\right]^{0.5} \\
& +(0.80 \pm 0.06) T_{\text {July }}\left({ }^{\circ} \mathrm{C}\right) \\
& -(0.25 \pm 0.03) T_{\text {Jan }}\left({ }^{\circ} \mathrm{C}\right) \\
& -(7.7 \pm 0.7) \text { Pacific Rim } \\
& +(7.5 \pm 1.0) \text { Arctic coast lines } R^{2}=0.803 \\
\log _{10} \text { LOI }(\%) & (0.246 \pm 0.028) \text { Precipitation }\left(\mathrm{m} \mathrm{a}^{-1}\right)
\end{aligned}
$$


TABLE 2: Mean sediment THg and LOI for streams and lakes, by Quebec survey zones (Figure 12).

\begin{tabular}{|c|c|c|c|c|c|c|c|c|c|c|}
\hline \multirow{2}{*}{ Quebec survey zone } & \multirow{2}{*}{ Medium } & \multirow{2}{*}{$n$} & \multicolumn{4}{|c|}{ Sediment THg $\left(\mathrm{ng} \mathrm{g}^{-1}\right)$} & \multicolumn{4}{|c|}{ Sediment LOI (\%) } \\
\hline & & & Mean & Min. & Max. & Std. Dev. & Mean & Min. & Max. & Std. Dev. \\
\hline Abitibi (22) & \multirow{11}{*}{ Lakes } & 299 & 104.1 & 5 & 422 & 68.7 & 33.6 & 2 & 88 & 15.9 \\
\hline Churchill (30) & & 18,496 & 118.2 & 5 & 1,500 & 93.1 & 26.9 & 1 & 98 & 19.9 \\
\hline Grenville (23) & & 764 & 105.6 & 5 & 339 & 56.1 & 32.4 & 2 & 80 & 12.2 \\
\hline Grenville (24) & & 5,768 & 109.6 & 5 & 490 & 56.3 & 34.8 & 2 & 94 & 14.6 \\
\hline Grenville (25) & & 4,831 & 105.9 & 5 & 639 & 66.9 & 27.3 & 2 & 98 & 14.1 \\
\hline Grenville (26) & & 17,104 & 108.6 & 5 & 9,820 & 137.5 & 30.2 & 1 & 98 & 19.1 \\
\hline Ashuanipi (28) & & 7,141 & 109.8 & 5 & 7,180 & 153.4 & 23.1 & 2 & 98 & 13.1 \\
\hline Minto (29) & & 1,325 & 80.0 & 6 & 376 & 39.4 & 31.8 & 2 & 92 & 19.1 \\
\hline Opatica (27) & & 12,389 & 185.4 & 10 & 7,410 & 243.7 & 28.1 & 1 & 98 & 21.7 \\
\hline Platform (18) & & 10 & 85.8 & 26 & 150 & 45.5 & 28.2 & 2 & 90 & 28.0 \\
\hline Total & & 68,127 & 124.6 & 5 & 9,820 & 131.4 & 28.4 & 1 & 98 & 18.4 \\
\hline Abitibi (22) & \multirow{13}{*}{ Streams } & 8,187 & 78.3 & 5 & 7,331 & 190.6 & 12.5 & 1 & 92 & 15.03 \\
\hline Abitibi (21) & & 151 & 69.6 & 5 & 1,400 & 126.3 & 18.1 & 1 & 91 & 19.59 \\
\hline Appalachian (19) & & 2,104 & 63.3 & 5 & 520 & 52.7 & 10.5 & 1 & 95 & 14.38 \\
\hline Appalachian (20) & & 7,956 & 144.8 & 5 & 1,435 & 114.6 & 30.5 & 1 & 97 & 20.00 \\
\hline Churchill (30) & & 1,057 & 135.7 & 5 & 980 & 124.3 & 30.1 & 1 & 92 & 18.62 \\
\hline Grenville (23) & & 8,434 & 234.5 & 5 & 9,392 & 442.5 & 13.4 & 1 & 94 & 17.18 \\
\hline Grenville (24) & & 1,262 & 56.6 & 5 & 933 & 57.2 & 10.2 & 2 & 96 & 11.24 \\
\hline Grenville (25) & & 1,462 & 62.4 & 5 & 354 & 53.1 & 17.5 & 2 & 100 & 20.21 \\
\hline Grenville (26) & & 287 & 79.9 & 10 & 412 & 55.2 & 18.6 & 2 & 92 & 15.02 \\
\hline Minto (29) & & 34 & 34.9 & 5 & 150 & 35.6 & 19.7 & 1 & 69 & 19.90 \\
\hline Opatica (27) & & 969 & 243.4 & 5 & 6,720 & 470.5 & 28.3 & 1 & 90 & 23.32 \\
\hline Platform (18) & & 13 & 18.2 & 10 & 57 & 13.8 & 2.1 & 1 & 4 & 0.64 \\
\hline Total & & 31,916 & 140.4 & 5 & 22,690 & 222.1 & 18.4 & 1 & 100 & 17.3 \\
\hline Total & & 100,043 & 129.6 & 5 & 22,690 & 160.3 & 25.2 & 1 & 100 & 18.0 \\
\hline
\end{tabular}

Calculated weighted mean and standard deviation (Std. Dev.) for locations with both THg and LOI values.

Opatica (27) represents the survey zone across the Opatica, Opinaca, and La Grande geological subprovinces.

$$
\begin{aligned}
& +(0.056 \pm 0.003) T_{\text {July }}\left({ }^{\circ} \mathrm{C}\right) \\
& -(0.020 \pm 0.001) T_{\text {Jan }}\left({ }^{\circ} \mathrm{C}\right) \\
& -(0.482 \pm 0.021)(\text { streams }=1, \text { lakes }=0)
\end{aligned}
$$

$$
R^{2}=0.703
$$

$$
\begin{array}{rl}
\log _{10} & \mathrm{THg}\left(\mathrm{ng} \mathrm{g}^{-1}, \text { lakes }\right) \\
= & (1.380 \pm 0.048) \\
& +(0.406 \pm 0.059) \text { Precipitation }\left(\mathrm{m} \mathrm{a}^{-1}\right) \\
& +(0.012 \pm 0.004) \text { atm. } \mathrm{Hg}_{\text {dep }}\left(\mu \mathrm{g} \mathrm{m}^{-2} \mathrm{a}^{-1}\right) \\
R^{2}= & 0.43 \\
\log _{10} \mathrm{THg}\left(\mathrm{ng} \mathrm{g}^{-1}, \text { streams }\right) \\
=(0.61 \pm 0.14)+(0.67 \pm 0.08) \log _{10} \mathrm{LOI}(\%) \\
+(0.031 \pm 0.007) T_{\text {July }}\left({ }^{\circ} \mathrm{C}\right) \quad R^{2}=0.434 .
\end{array}
$$$$
R^{2}=0.432
$$

In these equations, the numbers in brackets refer to the best-fitted least-squares regression coefficients and their \pm standard estimates of error. $R^{2}$ refers to the coefficient of determination. In detail, (3) quantifies how the GRAHM2005 results for atm. $\mathrm{Hg}_{\text {dep }}$ are related to the Canada-wide rasters for precipitation, $T_{\text {July }}$, and $T_{\text {Jan }}$. In principle, net retention of atmospheric $\mathrm{Hg}$ is therefore facilitated by vegetationbased $\mathrm{Hg}$ uptake and sequestration, which increases from cold to warm and from dry to wet regions. In contrast, increasing January temperatures lower $\mathrm{Hg}$ retention likely through increased $\mathrm{Hg}$ volatility year-round [4]. Note that the (3) implied dependency of atm. $\mathrm{Hg}_{\text {dep }}$ on mean annual precipitation is not linear, likely due to increasing dilution with increasing precipitation. Along the high precipitation region along the Pacific coast, this dilution becomes even stronger, as captured by the introduction of the locator variable for the NTS tiles along the Pacific Rim (coded 1 when applicable and 0 otherwise). In addition, (3) introduces an adjustment for the increased presence and net retention of atmospheric $\mathrm{Hg}$ along arctic costs (coded 1 when applicable and 0 otherwise) due to oceanic $\mathrm{Hg}$ upwelling [2].

Generally, stream LOI is lower than lake LOI, with the latter covering the 0 to $100 \%$ range but peaking at about 


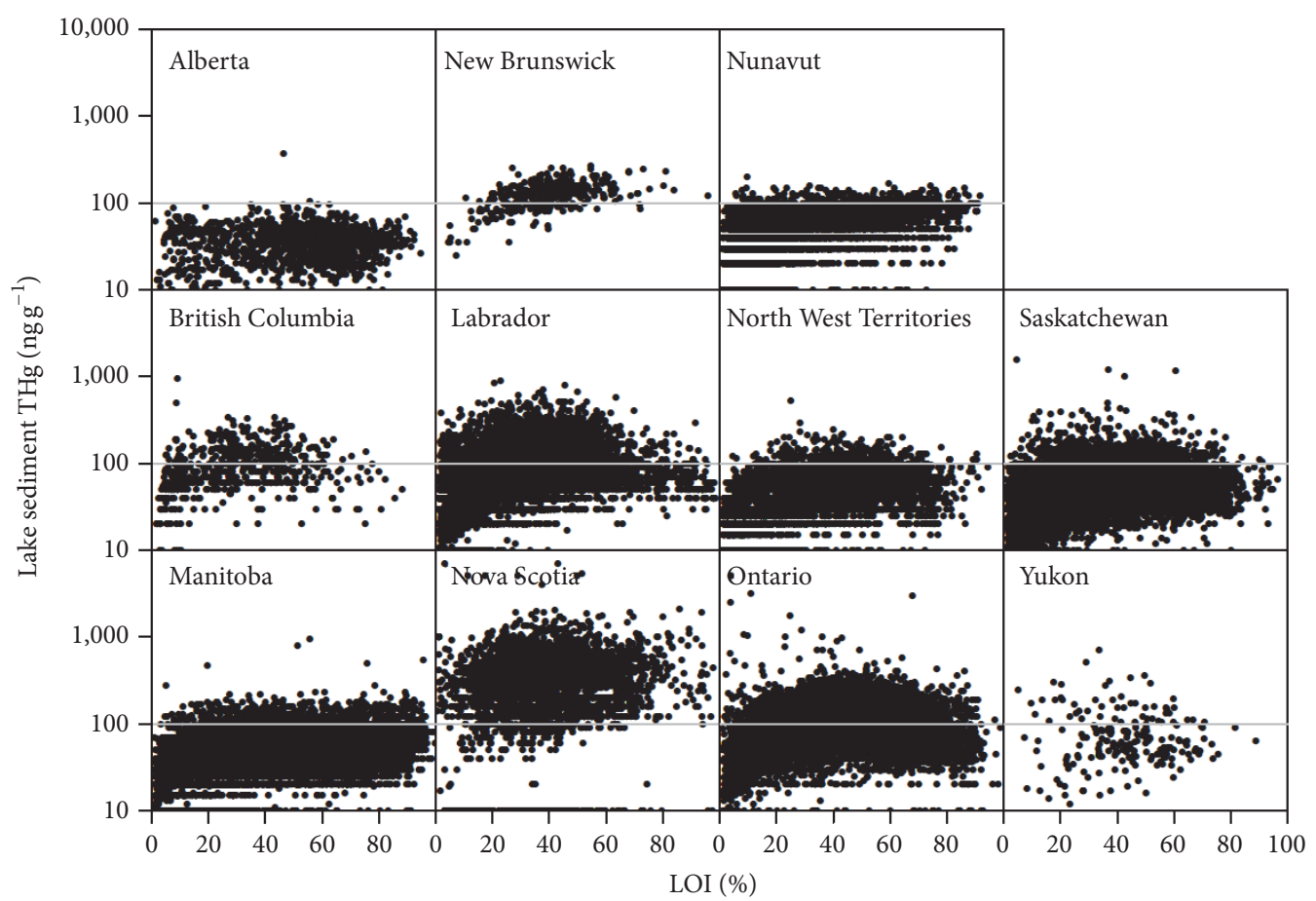

(a)

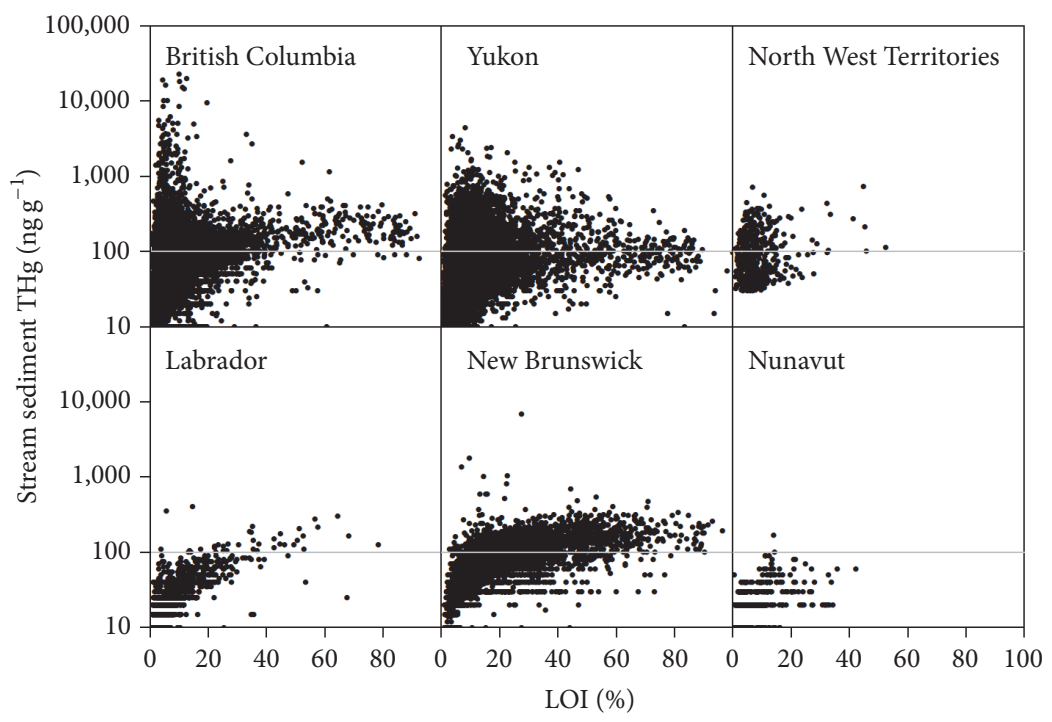

(b)

FIgURE 3: Scatterplots of lake (a) and stream (b) sediment THg (ng $\mathrm{g}^{-1}, \log _{10}$ scale) versus LOI (\%) by provinces/territories across Canada.

$35 \%$. Furthermore, stream LOI is most frequent below LOI $\approx 20 \%$. In contrast, lake and stream sediment $\mathrm{THg}$ values are most frequent at about $\mathrm{THg} \approx 100 \mathrm{ng} \mathrm{g}^{-1}$, with stream $\mathrm{THg}$ somewhat more variable than lake THg (Figure 5).

Equation (4) indicates that $\log _{10} \mathrm{LOI}$ for lake and stream sediments both increase with increasing precipitation and $T_{\text {July }}$ and decreasing $T_{\text {Jan }}$. This is quite similar to the atmTH $H_{\text {dep }}$ pattern, likely due to the parallel dependence on terrestrial and aquatic organic matter production (which generally increases with precipitation and $T_{\text {July }}$ ) and organic matter retention (which generally increases with decreasing $T_{\text {Jan }}$
$[59,60])$. Also note that the stream/lake variable (coded 1 for streams and 0 for lakes) sets LOI (streams) $=0.33$ LOI (lakes); that is, the organic matter concentrations in stream sediments are, on average, two-thirds lower than in lake sediments.

Equations (5) and (6) specify that the dependency of sediment $\mathrm{THg}$ on atm. $\mathrm{Hg}_{\text {dep }}$ differs from streams to lakes, with stream $\mathrm{THg}$ variations most strongly related to variations in LOI, while lake $\mathrm{THg}$ varies more directly with variations in precipitation and atmTHg $\mathrm{Tep}_{\text {ep }}$. Direct relationships between increasing atmospheric $\mathrm{Hg}$ deposition and increasing sediment $\mathrm{THg}$ have been noted repeatedly for 


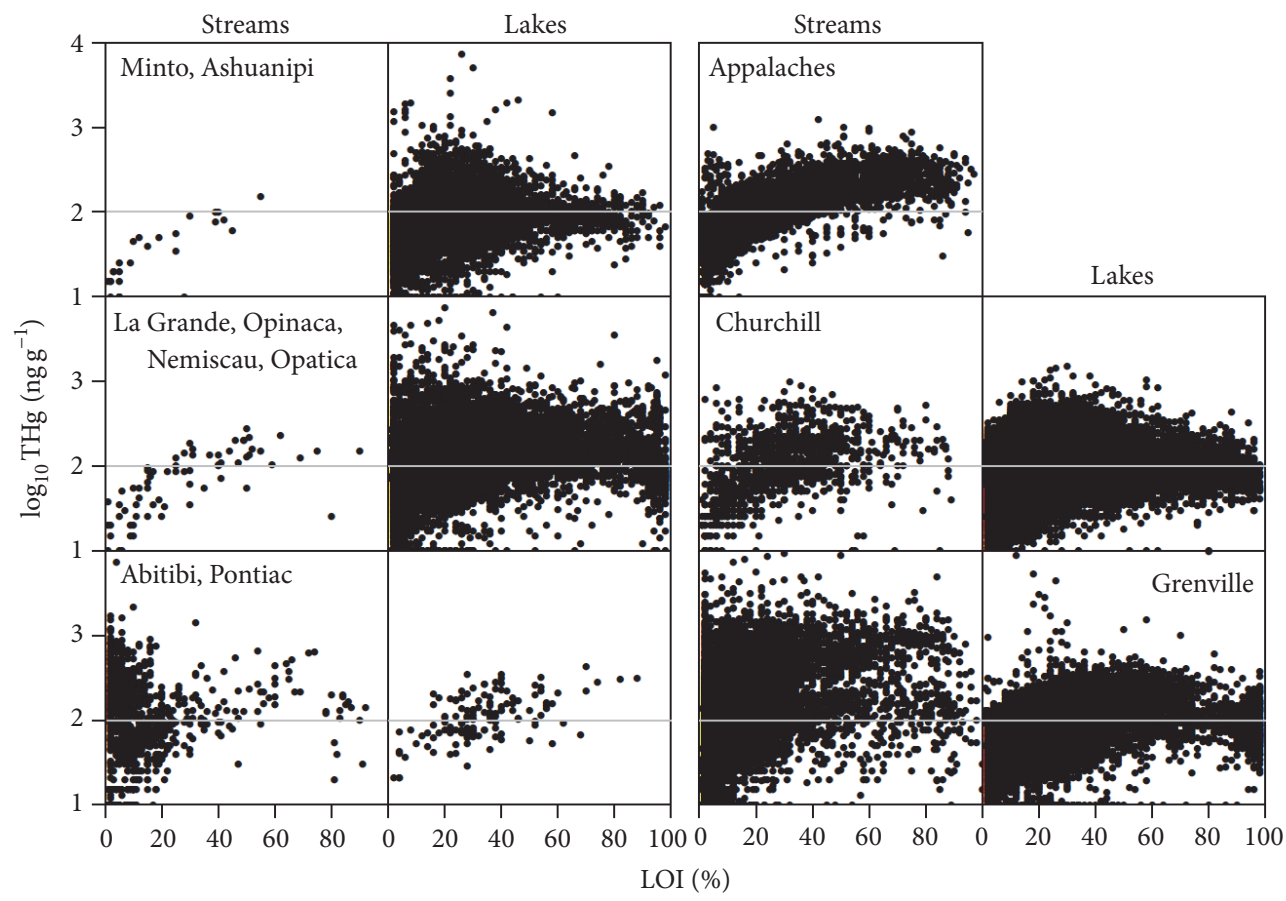

FIGURE 4: Scatterplots of lake and stream sediment THg $\left(\mathrm{ng} \mathrm{g}^{-1}, \log _{10}\right.$ scale) versus LOI (\%) by Quebec survey zones.
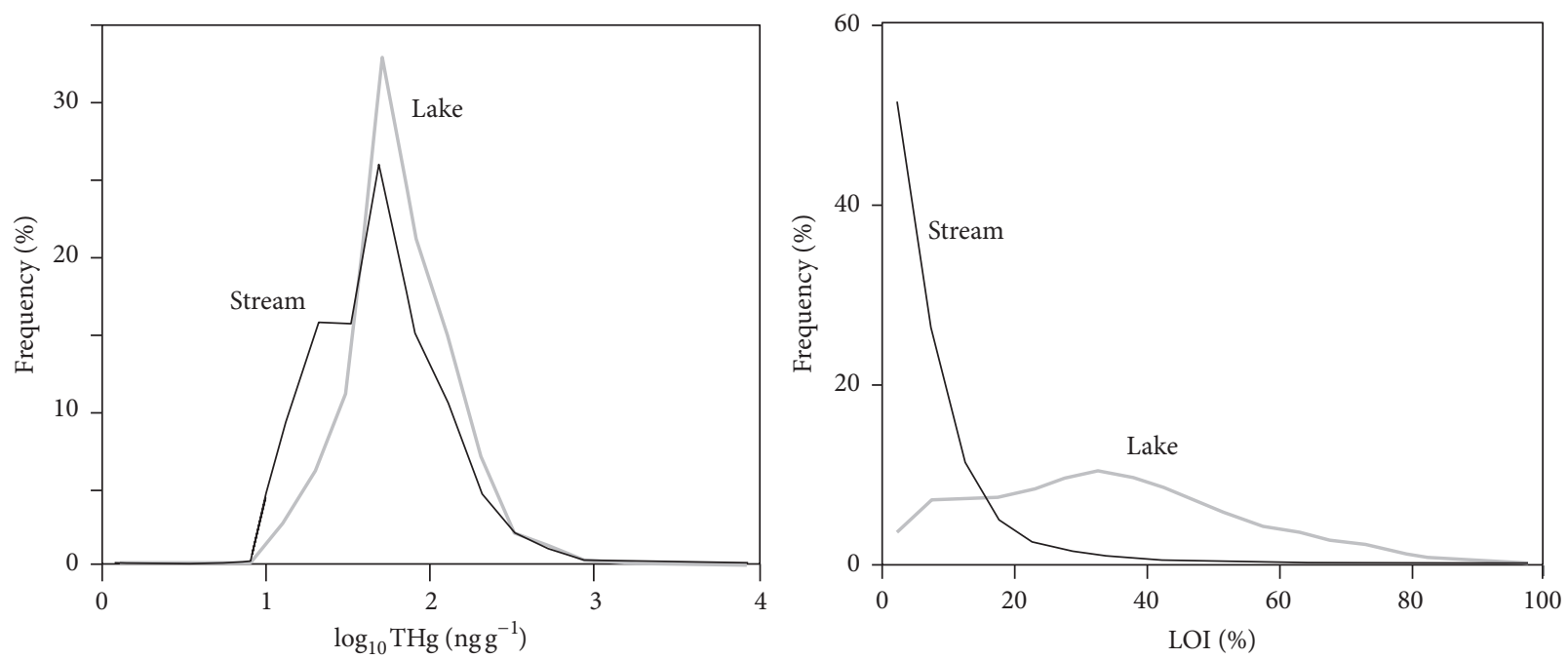

FigurE 5: Frequency diagram for the compiled THg $\left[\log _{10}\left(\mathrm{ng} \mathrm{g}^{-1}\right)\right]$ and LOI (\%) data across Canada.

lakes by, for example, (i) Muir et al. [23] across northern Quebec, (ii) Munthe et al. [33] across Scandinavia, and (iii) Hissler and Probst [21] downwind from industrial $\mathrm{Hg}$ emissions in France. Equations (5) and (6) also predict that decreases in atm. $\mathrm{Hg}_{\text {dep }}$ due to reductions in Hg emissions should eventually lead to reductions in sediment $\mathrm{THg}$, as documented by Kamman and Engstrom [61]. Such reductions would be more readily observed for lake than for stream sediments.

Using (4), (5) and (6) produced the maps for sediment $\mathrm{Hg}$ and LOI in Figure 7. Overlaying the mean GSC data values for $\log _{10} \mathrm{THg}$ and $\log _{10} \mathrm{LOI}$ values per NTS-tile (dots) on these maps underscores the general conformance between the mapped and NTS-tile averaged $\log _{10} \mathrm{THg}$ values. This is further demonstrated in Figure 8 by way of cumulative frequency plots regarding the absolute differences between the mapped and NTS-tile averaged $\log _{10} \mathrm{THg}$ and $\log _{10} \mathrm{LOI}$ values. The extent of lake versus stream map-to-dot conformances is approximately the same, with $80 \%$ of the model projections falling within the $\log _{10} \mathrm{Hg}$ and $\log _{10} \mathrm{LOI}$ residual range of -0.2 to 0.2 .

In principle, (3) implies that sustained precipitation increases by $0.1 \mathrm{~m}$ at $1 \mathrm{~m}$ per year would, on average, add $2.68 \mu \mathrm{g} \mathrm{m}^{-2}$ to atm. $\mathrm{Hg}_{\text {dep }}$. Similarly, the temperature entries 


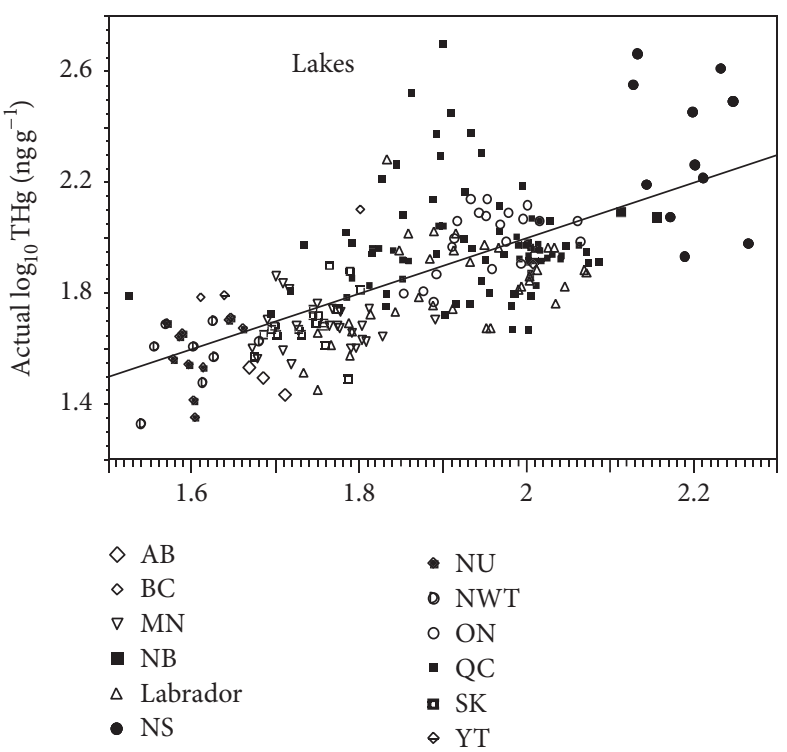

(a) Best-fitted $\log _{10} \mathrm{THg}\left[\log _{10}\left(\mathrm{ng} \mathrm{g}^{-1}\right)\right](5)$

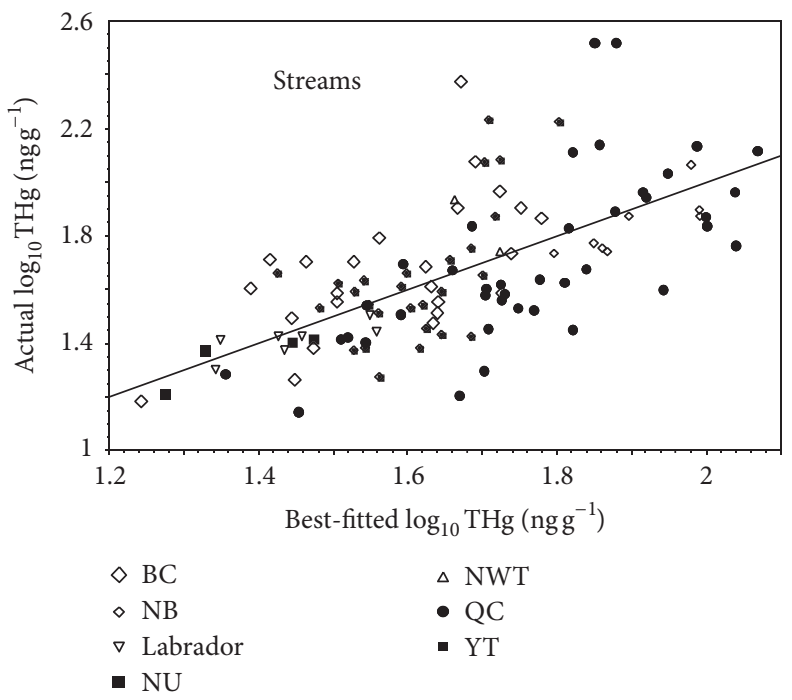

(c) Best-fitted $\log _{10} \mathrm{THg}\left[\log _{10}\left(\mathrm{ng} \mathrm{g}^{-1}\right)\right](6)$

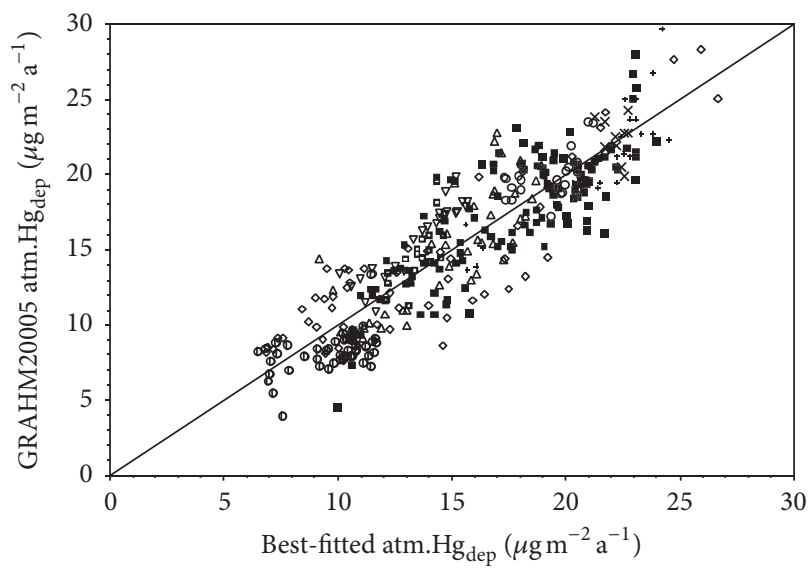
$\diamond \mathrm{AB}$
$\diamond \mathrm{NU}$
$\diamond \mathrm{BC}$
- NWT
$\nabla \mathrm{MN}$
- ON
$\times \mathrm{NB}$
- $\mathrm{QC}$
$\triangle \mathrm{Lab}$
- SK
+ NS
- YT

(b) Best-fitted GRAHM2005 atm.Hg $\operatorname{Hep}_{\text {dep }}\left(\mu \mathrm{g} \mathrm{m}^{-2} \mathrm{a}^{-1}\right)$ (3)

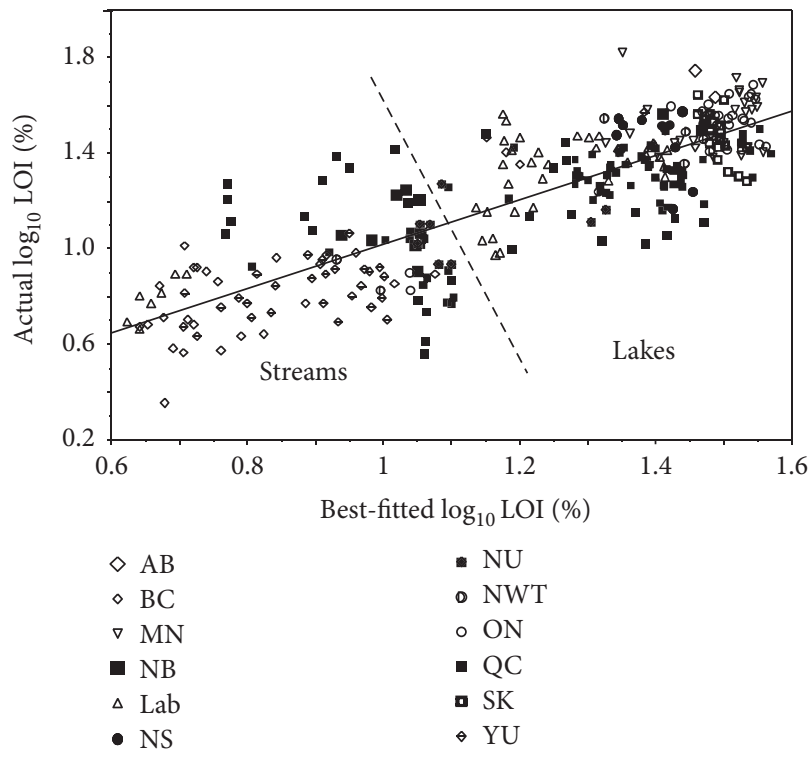

(d) Best-fitted LOI $\left[\log _{10}(\%)\right](4)$

FIGURE 6: Scatterplots of actual versus least-squares best-fitted (i) lake (a) and (ii) stream (c) sediment $\log _{10} \mathrm{THg}\left[\log _{10}\left(\mathrm{ng} \mathrm{g}^{-1}\right)\right]$, (iii) GRAHM2005 atmospheric Hg deposition ((b); model), and (iv) stream and lake sediment $\log _{10} \mathrm{LOI}((\mathrm{d})$; dashed line separates the lake from the stream dots); all symbolized by provinces/territories (Table 5).

in (3) imply that an increase of $1^{\circ} \mathrm{C}$ in July temperature would, on average, increase atm. $\mathrm{Hg}_{\text {dep }}$ by $0.80 \mu \mathrm{g} \mathrm{m}^{-2} \mathrm{a}^{-1}$. A parallel increase of $1^{\circ} \mathrm{C}$ in January air temperatures, however, would compensate for some of that increase by $0.25 \mu \mathrm{g} \mathrm{m}^{-2} \mathrm{a}^{-1}$, thereby resulting in a mean increase in atm. $\mathrm{Hg}_{\text {dep }}$ of $0.55 \pm$ $0.09 \mathrm{SD} \mu \mathrm{g} \mathrm{m}^{-2}$. According to Barrow et al. [62], summer and winter temperatures will increase by about 5 to $6^{\circ} \mathrm{C}$ at, for example, Resolute Bay (southwest corner of Cornwallis Island; southeast of Bathurst Island, NU) by 2050. Based on (3), this translates into a net gain in atm. $\mathrm{Hg}_{\text {dep }}$ rate of about
$3.0 \mu \mathrm{g} \mathrm{m}^{-2} \mathrm{a}^{-1}$. In turn, (5) implies that lake sediment $\mathrm{THg}$ would then increase as well by almost a factor of 10 . Further south at Norman Wells (along the Mackenzie river, west of Great Bear Lake, NWT), the effect on atm.Hg dep would be somewhat smaller, with summer and winter temperatures expected to increase by about 2 to $3^{\circ} \mathrm{C}$ while the growing season would increase by about a month [62].

As indicated by the $R^{2}$ values, the climate and regional predictor variables of (3) to (6) account for $80 \%$ of the atm. $\mathrm{Hg}_{\text {dep }}$ variations, followed by $70 \%$ of the $\log _{10} \mathrm{LOI}$ 


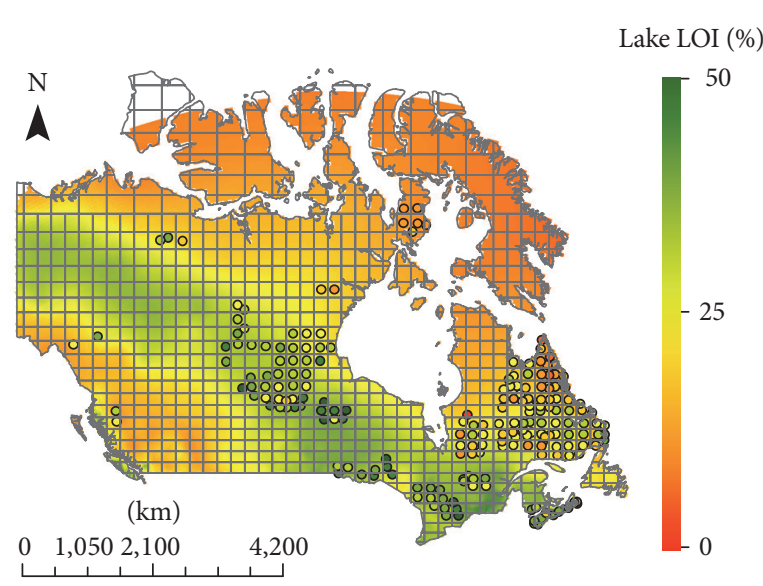

(a)

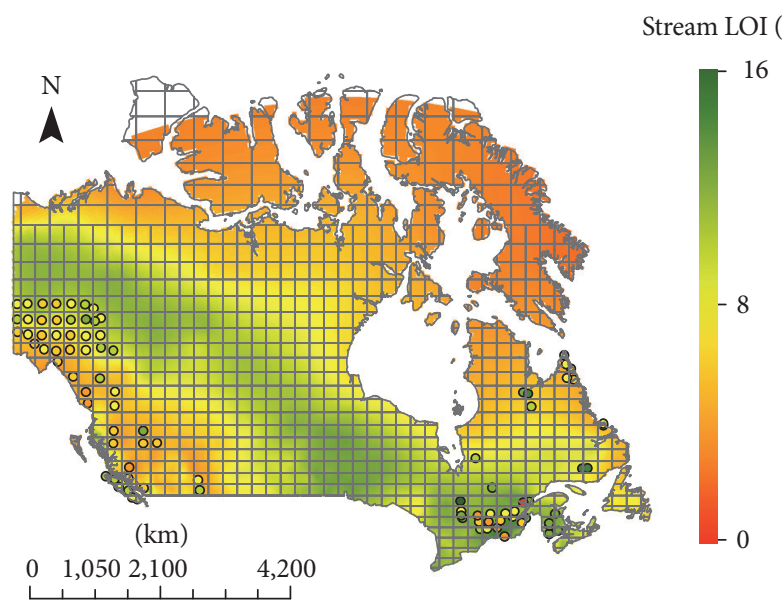

(c)

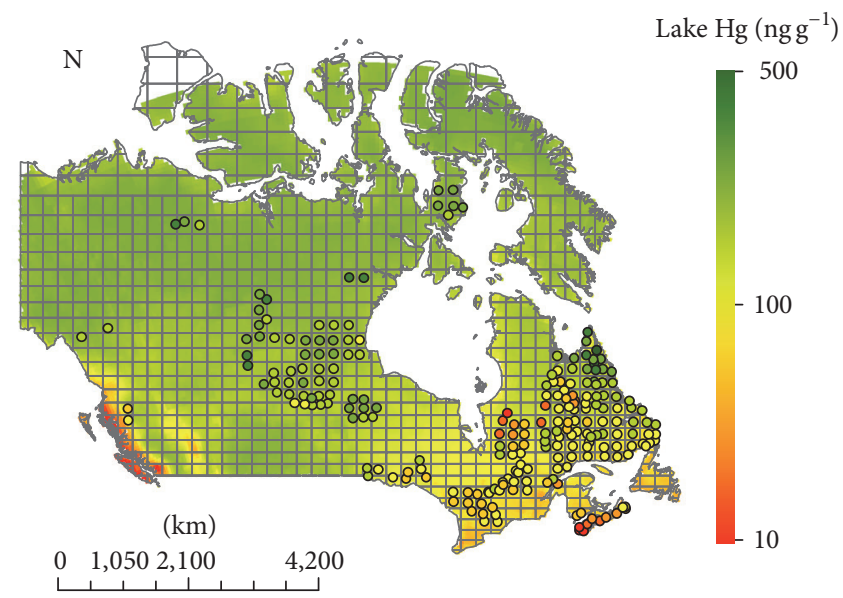

(b)

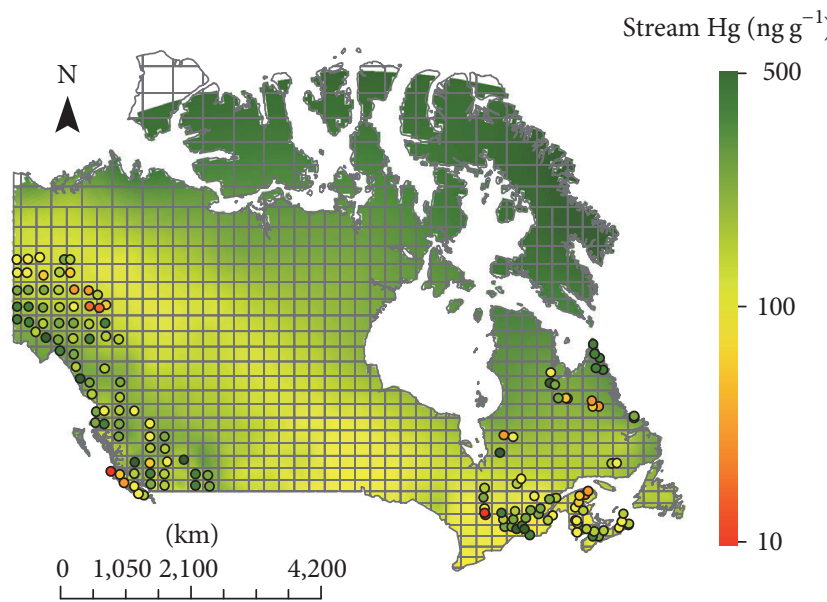

(d)

Figure 7: Sediment LOI (\%) and THg (ng ${ }^{-1}, \log _{10}$ scale) projected across Canada using (2)-(4). Overlaid dots: mean sediment THg value per NTS tile. ( $a$ and b) Lakes; (c and d) streams.

variations, and $40 \%$ of the $\log _{10} \mathrm{THg}$ variations. The unaccounted variations would be related to (i) local variations in $\mathrm{Hg}$ emission and deposition, (ii) the extent of vegetation cover upslope from the sampling locations, and (iii) the extent of upslope exposures of $\mathrm{Hg}$-containing minerals [3].

\subsection{Analyzing and Interpreting the 10th and 90th Percentiles of} the THg versus LOI Scatter Plots. Determining and plotting the 10th and 90th percentiles of the sediment $\log _{10} \mathrm{THg}$ variations within each of the $10 \%$ LOI classes from 0 to $100 \%$ produced dots in Figure 9 for each of the provinces/territories and Quebec survey zones. These dots follow fairly consistent pattern, being highest at intermediate LOI values as implied by (1).

Curve-fitting the dots in Figure 9 with (1) produced the best-fitted lines and $a_{i j}$, $b_{i j}$, and $c_{j}$ coefficients in Table 4. Recognizing the similarity of these lines across the provinces/territories and Quebec survey zones led to a further best-fitted simplification by setting $a_{i j}$ (90th percentile) $=0.668+a_{i j}$ (10th percentile). This implies that, on average,
$\mathrm{THg}(90$ th percentile $)=4.87 \mathrm{THg}(10$ th percentile $)$ when LOI $=0 \%$.

Since $a_{i j}$ represents the mineral component of sediment THg at $\mathrm{LOI}=0 \%$, it follows that the 10th and 90th percentiles bracket the lake and stream sediment THg within the following ranges:

$$
\begin{aligned}
& \text { for lakes, } 14<\mathrm{THg}\left(\mathrm{ng} \mathrm{g}^{-1}\right)<69 \text { since } 1.15<a_{i j} \text { (lakes) } \\
& <1.84 ; \\
& \text { for streams, } 12<\mathrm{THg}\left(\mathrm{ngg}^{-1}\right)<59 \text { since } 1.08<a_{i j} \\
& \text { (streams) }<1.77 .
\end{aligned}
$$

This suggests that the variations in lake and stream $\mathrm{THg}$ at $\mathrm{LOI}=0 \%$ are similar to the $\mathrm{THg}$ variations in till deposits when not influenced by local Hg-containing mineral exposures (see, e.g., Broster et al. [9, 63]).

3.4. Sensitivity of the $a_{i j}$ and $b_{i j}$ to Atmospheric Deposition. Regressing the $a_{i j}$ values against the mean atm. $\mathrm{Hg}_{\text {dep }}$ and precipitation values per NTS tile (Table 3) produces no significant trends. In contrast, the $b_{i j}$ coefficients in Table 4 
TABLE 3: Mean annual precipitation, mean atmospheric deposition, and best-fitted $a_{i j}, b_{i j}$, and $c_{j}$ values (1) for the 10 th and 90 th sediment THg percentiles (lakes, streams), by provinces/territories and by Quebec survey zones (Figure 12).

\begin{tabular}{|c|c|c|c|c|c|c|c|c|c|c|}
\hline \multirow{3}{*}{ Location } & \multirow{3}{*}{ Medium } & \multirow{3}{*}{$\begin{array}{l}\text { Precipitation } \\
\qquad \mathrm{M} \mathrm{a}^{-1}\end{array}$} & \multirow{3}{*}{$\begin{array}{l}\operatorname{atm} \cdot \mathrm{Hg}_{\mathrm{dep}} \\
\mu \mathrm{g} \mathrm{m}^{-2} \mathrm{a}^{-1}\end{array}$} & \multirow{3}{*}{$\begin{array}{r}a_{i j} \\
10 \text { th }\end{array}$} & \multirow{2}{*}{\multicolumn{2}{|c|}{$b_{i j}$}} & \multicolumn{4}{|c|}{ Sediment THg, ng g $^{-1}$} \\
\hline & & & & & & & \multicolumn{2}{|c|}{$\mathrm{LOI}=0 \%$} & \multicolumn{2}{|c|}{$\mathrm{LOI}=100 \%$} \\
\hline & & & & & 10th & 90th & 10th & 90th & 10th & 90th \\
\hline \multicolumn{11}{|l|}{ Quebec (QC) } \\
\hline Abitibi (22) & \multirow{10}{*}{ Lakes } & 0.95 & 20.0 & 1.13 & 2.25 & 2.66 & 13.4 & 65.1 & 74.6 & 163.5 \\
\hline Churchill (30) & & 0.64 & 13.0 & 1.24 & 1.93 & 2.42 & 17.5 & 85.4 & 40.6 & 103.0 \\
\hline Grenville (23) & & 0.96 & 20.2 & 1.09 & 2.43 & 2.64 & 12.3 & 59.7 & 104.8 & 157.4 \\
\hline Grenville (24) & & 0.98 & 20.4 & 1.19 & 2.23 & 2.58 & 15.6 & 75.9 & 71.4 & 139.7 \\
\hline Grenville (25) & & 0.97 & 17.9 & 1.12 & 1.74 & 2.52 & 13.2 & 64.2 & 28.4 & 125.8 \\
\hline Grenville (26) & & 1.05 & 19.1 & 1.08 & 2.17 & 2.58 & 12.0 & 58.3 & 64.3 & 140.8 \\
\hline Ashuanipi (28) & & 0.76 & 15.6 & 1.33 & 1.93 & 2.42 & 21.5 & 104.7 & 40.5 & 103.6 \\
\hline Minto (29) & & 0.61 & 14.3 & 1.22 & 2.00 & 2.42 & 16.7 & 81.6 & 46.8 & 104.1 \\
\hline Opatica (27) & & 0.82 & 20.4 & 1.35 & 2.12 & 2.82 & 22.3 & 108.7 & 57.8 & 223.7 \\
\hline Platform (18) & & 1.09 & 15.7 & 1.14 & 2.25 & 2.6 & 13.7 & 67 & 74.6 & 147.2 \\
\hline \multicolumn{11}{|l|}{ Province/territories } \\
\hline QC & \multirow{12}{*}{ Lakes } & 0.85 & 17.3 & 1.27 & 2.16 & 2.79 & 18.4 & 89.8 & 62.7 & 210.3 \\
\hline $\mathrm{AB}$ & & 0.40 & 12.1 & 0.82 & 1.64 & 1.97 & 6.6 & 32.4 & 23.1 & 43.4 \\
\hline $\mathrm{BC}$ & & 0.79 & 11.1 & 1.42 & 1.77 & 2.25 & 26.3 & 128.4 & 30.0 & 74.2 \\
\hline MB & & 0.47 & 15.7 & 0.95 & 1.93 & 2.23 & 8.9 & 43.5 & 40.8 & 72.7 \\
\hline NB & & 1.28 & 21.8 & 1.22 & 2.59 & 2.56 & 16.6 & 80.9 & 143.2 & 134.7 \\
\hline NL & & 0.88 & 16.1 & 1.17 & 2.07 & 2.51 & 14.9 & 72.4 & 53.2 & 123.9 \\
\hline NS & & 1.39 & 24.1 & 1.46 & 2.51 & 3.52 & 29.0 & 141.3 & 124.2 & 850.3 \\
\hline $\mathrm{NU}$ & & 0.30 & 9.8 & 0.86 & 2.13 & 2.42 & 7.2 & 35.0 & 59.9 & 103.4 \\
\hline NWT & & 0.31 & 9.4 & 0.84 & 1.93 & 2.40 & 6.9 & 33.6 & 40.7 & 100.5 \\
\hline $\mathrm{ON}$ & & 0.86 & 20.1 & 1.30 & 1.96 & 2.48 & 20.0 & 97.6 & 42.9 & 116.7 \\
\hline SK & & 0.46 & 14.3 & 0.97 & 1.91 & 2.28 & 9.4 & 45.9 & 39.2 & 79.9 \\
\hline YT & & 0.36 & 9.5 & 1.13 & 1.77 & 2.42 & 13.4 & 65.2 & 29.6 & 103.5 \\
\hline \multicolumn{11}{|l|}{ Quebec (QC) } \\
\hline Abitibi (22) & \multirow{12}{*}{ Streams } & 0.88 & 21.1 & 1.61 & 2.71 & 3.44 & 40.4 & 196.7 & 180.2 & 731.0 \\
\hline Abitibi (21) & & 0.95 & 19.5 & 0.94 & 2.15 & 2.71 & 8.8 & 42.9 & 61.3 & 181.1 \\
\hline Appalachian (19) & & 1.16 & 21.6 & 1.04 & 2.32 & 2.67 & 11.1 & 53.9 & 86.4 & 167.0 \\
\hline Appalachian (20) & & 0.95 & 19.8 & 1.15 & 2.59 & 2.88 & 14.0 & 68.1 & 143.7 & 251.3 \\
\hline Churchill (30) & & 0.69 & 11.5 & 1.18 & 1.88 & 2.76 & 15.2 & 74.2 & 36.9 & 199.5 \\
\hline Grenville (23) & & 1.00 & 20.1 & 1.37 & 1.93 & 3.52 & 23.4 & 114.1 & 40.2 & 848.6 \\
\hline Grenville (24) & & 1.08 & 21.2 & 0.95 & 2.49 & 2.73 & 8.8 & 43.1 & 118.7 & 188.5 \\
\hline Grenville (25) & & 1.08 & 18.7 & 1.04 & 2.31 & 2.64 & 10.9 & 53.3 & 84.5 & 159.7 \\
\hline Grenville (26) & & 1.05 & 19.1 & 0.97 & 2.50 & 2.68 & 9.4 & 45.6 & 121.9 & 171.7 \\
\hline Minto (29) & & 0.58 & 12.6 & 0.83 & 2.42 & 2.80 & 6.8 & 33.3 & 103.4 & 215.9 \\
\hline Opatica (27) & & 0.75 & 18.1 & 0.71 & 2.41 & 2.84 & 5.1 & 25.0 & 101.8 & 232.2 \\
\hline Platform (18) & & 1.07 & 25.8 & 0.94 & 1.84 & 2.64 & 8.6 & 42.1 & 33.8 & 159.1 \\
\hline \multicolumn{11}{|l|}{ Provinces/territories } \\
\hline QC & \multirow{7}{*}{ Streams } & 0.96 & 20.0 & 1.29 & 2.16 & 3.48 & 19.6 & 95.3 & 62.9 & 798.3 \\
\hline $\mathrm{BC}$ & & 1.09 & 14.3 & 1.04 & 2.62 & 3.05 & 10.9 & 53.3 & 152.3 & 344.6 \\
\hline NB & & 1.15 & 22.2 & 1.09 & 2.55 & 2.86 & 12.3 & 59.8 & 132.5 & 239.7 \\
\hline NL & & 0.63 & 11.0 & 0.82 & 2.56 & 2.90 & 6.6 & 32.3 & 135.5 & 261.4 \\
\hline NU & & 0.30 & 7.4 & 0.82 & 1.90 & 1.99 & 6.6 & 32.2 & 38.2 & 45.6 \\
\hline NWT & & 0.32 & 8.0 & 1.53 & 1.57 & 2.46 & 33.8 & 164.8 & 20.4 & 111.9 \\
\hline YT & & 0.36 & 9.49 & 1.28 & 2.01 & 2.58 & 19.0 & 92.6 & 47.1 & 139.8 \\
\hline
\end{tabular}

$a_{i j}(90$ th $)=a_{i j}(10$ th $)+(0.688 \pm \mathrm{SE} 0.018) ; a_{i j}$ and $b_{i j}$ standard error of estimate (Std. Err.: SE) $= \pm 0.15 ; c_{j}=0.0180 \pm \mathrm{SE} 0.0011 ; a_{i j}$ and $b_{i j}$ in $\log _{10}\left(\mathrm{ng} \mathrm{g}{ }^{-1}\right) . \mathrm{Units}$ for $a_{i j}$ and $b_{i j}$ : $\left[\log _{10}\left(\mathrm{ng} \mathrm{g}^{-1}\right)\right]$. Excluded: ON stream sediments due to small sample size $(n=287)$ and insufficient number of values for the 10th and 90 th percentiles. 


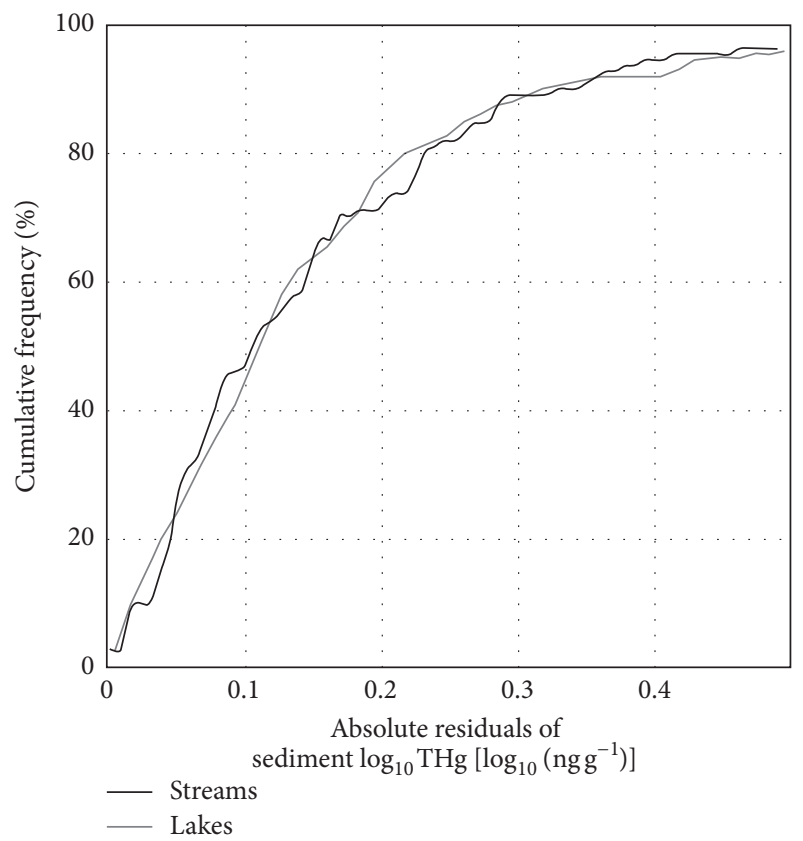

(a)

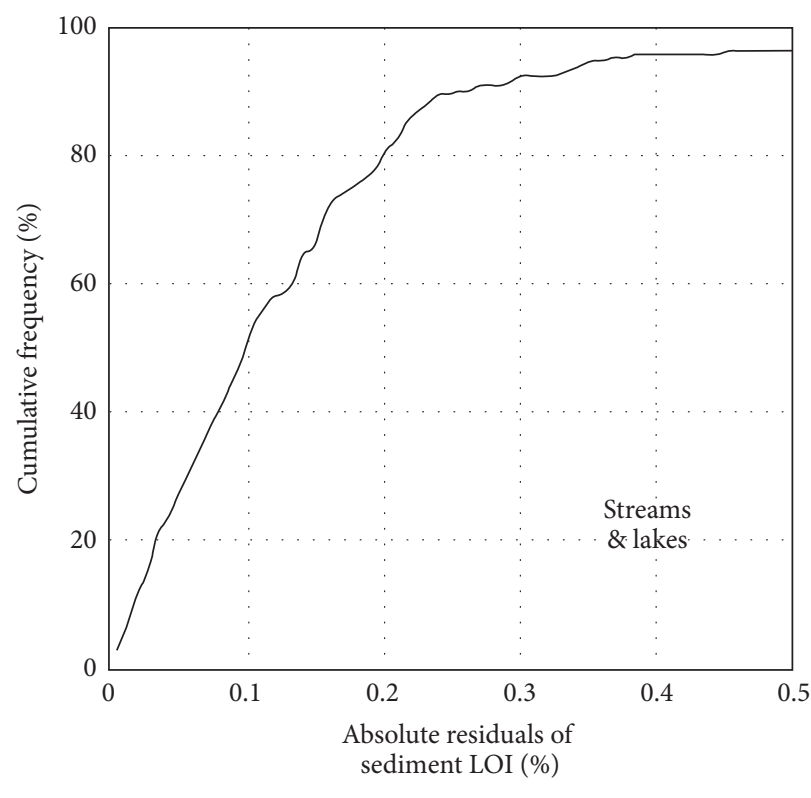

(b)

FIGURE 8: Conformance plots: cumulative frequency of the best-fitted absolute residual differences for stream and $\operatorname{lake} \log _{10} \mathrm{THg}\left(\left[\log _{10}\right.\right.$ $\left.\left.\left(\mathrm{ng} \mathrm{g}^{-1}\right)\right](\mathrm{a})\right)$ and $\log _{10}$ LOI (b) between (i) the NTS-tile averaged dots and (ii) the corresponding equations (2)-(4) projected map values in Figure 7.

are linearly related to atm. $\mathrm{Hg}_{\text {dep }}$ and precipitation (Figure 10, Table 4), with $R^{2}$ values near 0.50 for lakes, and less so for streams with $R^{2}$ values at 12 to $23 \%$. Hence, the organic contributions to sediment THg vary from being low to high as mean annual amounts for atm. $\mathrm{Hg}_{\text {dep }}$ and precipitation vary from low to high.

With the mineral and organic matter contributions to sediment THg quantified by way of the best-fitted $a_{i j}, b_{i j}$, and $c_{j}$ coefficients in Table 4 and (1), one can now estimate the organically induced gain of sediment $\mathrm{THg}$ from low to high atmospheric deposition environments via (2) as per Figure 10 and Table 1. For lake and stream sediments at LOI $=100 \%$, the estimated gain amounts to a factor of 4.4 to 6.0 as mean annual precipitation increases from near zero to $1.4 \mathrm{~m} \mathrm{a}^{-1}$. Similarly, the estimated gain for lake sediments increases even further to a factor of about 7.8 to 10.5 when based on increasing atm. $\mathrm{Hg}_{\text {dep }}$ from near zero to $26 \mu \mathrm{g} \mathrm{m} \mathrm{a}^{-2} \mathrm{a}^{-1}$ but remains low for streams at about 2.9 to 4.5 (Table 1).

\subsection{Mapping the Atmospherically Induced Sediment $\mathrm{THg}$} Gains across Canada. Using (4), (5), and (6) to calculate the organically induced gains for sediment $\mathrm{THg}$ via (2) produced the maps in Figure 11. These maps suggest lake sediments are particularly prone to atm. $\mathrm{Hg}_{\text {dep }}$-related $\mathrm{THg}$ acquisition across southeastern Canada and along the Pacific Rim. From there, this susceptibility is mapped to decrease towards the alpine areas and the boreal to arctic zones in the north.

The overlaid dots on the maps in Figure 11(a) are also generated from (2) but represent the sediment THg gains using NTS-averaged atm.THg dep (GRAHM 2005 raster) and
GSC-surveyed LOI (\%) values as gain predictors. These dotto-map patterns suggest a general conformance between the mapped and dotted THg gains. However, major differences occur as well:

(i) Across northern Alberta, Saskatchewan, and Manitoba, lakes with high sediment organic matter content appear to be particularly sensitive to increasing atm. $\mathrm{Hg}_{\text {dep }}$. The more sensitive lakes occur in flat terrain (Figure 11(b); for details regarding the flat-area shading, see [3]).

(ii) In areas with rugged terrain, frequent streambed scouring leads to high mineral and low organic matter inputs into lake and stream sediments. This, in turn, would lower the atm. $\mathrm{Hg}_{\text {dep }}$ induced gain of the organic matter contributions to sediment THg.

(iii) Downstream from open nonforested areas much of the atmospherically deposited $\mathrm{Hg}$ would revolatilize. This would be the case in southeastern Quebec landscape where open field conditions dominate.

(iv) Downstream from upland areas where sediment $\mathrm{Hg}$ would accumulate on account of (a) significant $\mathrm{Hg}$ containing mineral exposures and/or (b) air- or waterborne $\mathrm{Hg}$ emissions due to industrial activities.

\section{Concluding Remarks}

The linear regression results ( (3) to (6)) revealed a strong interdependence between the NTS-tile averaged values for sediment $\mathrm{THg}$, sediment LOI, atm. $\mathrm{Hg}_{\mathrm{dep}}$, and climate across 


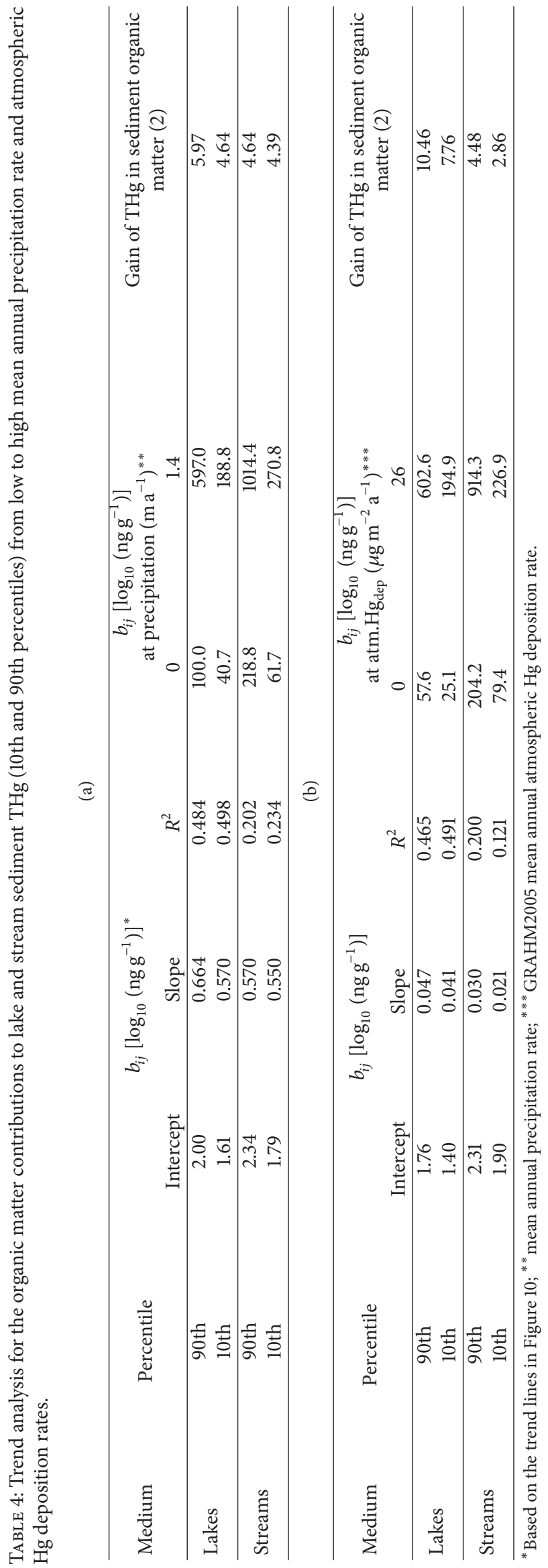




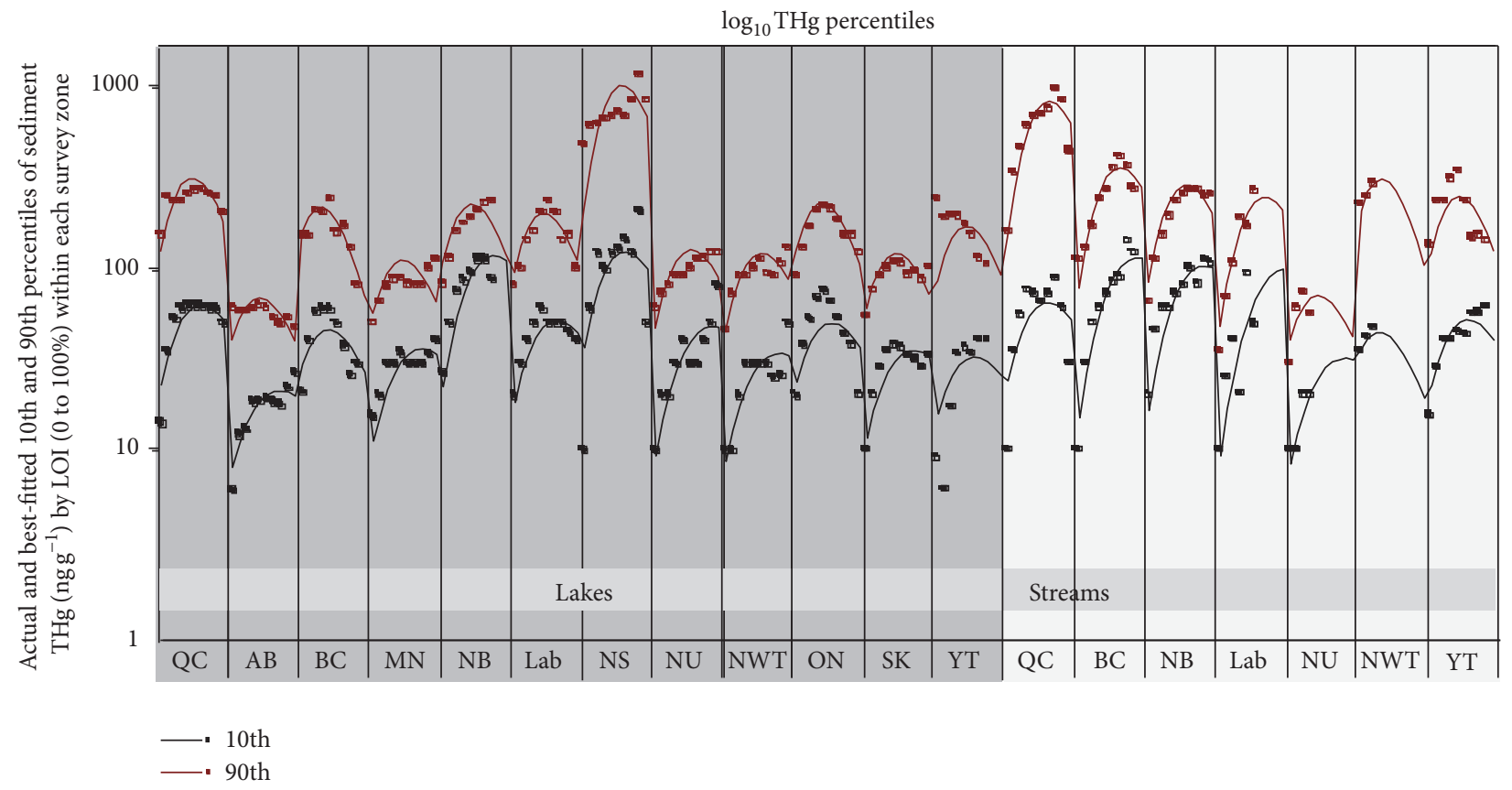

(a)

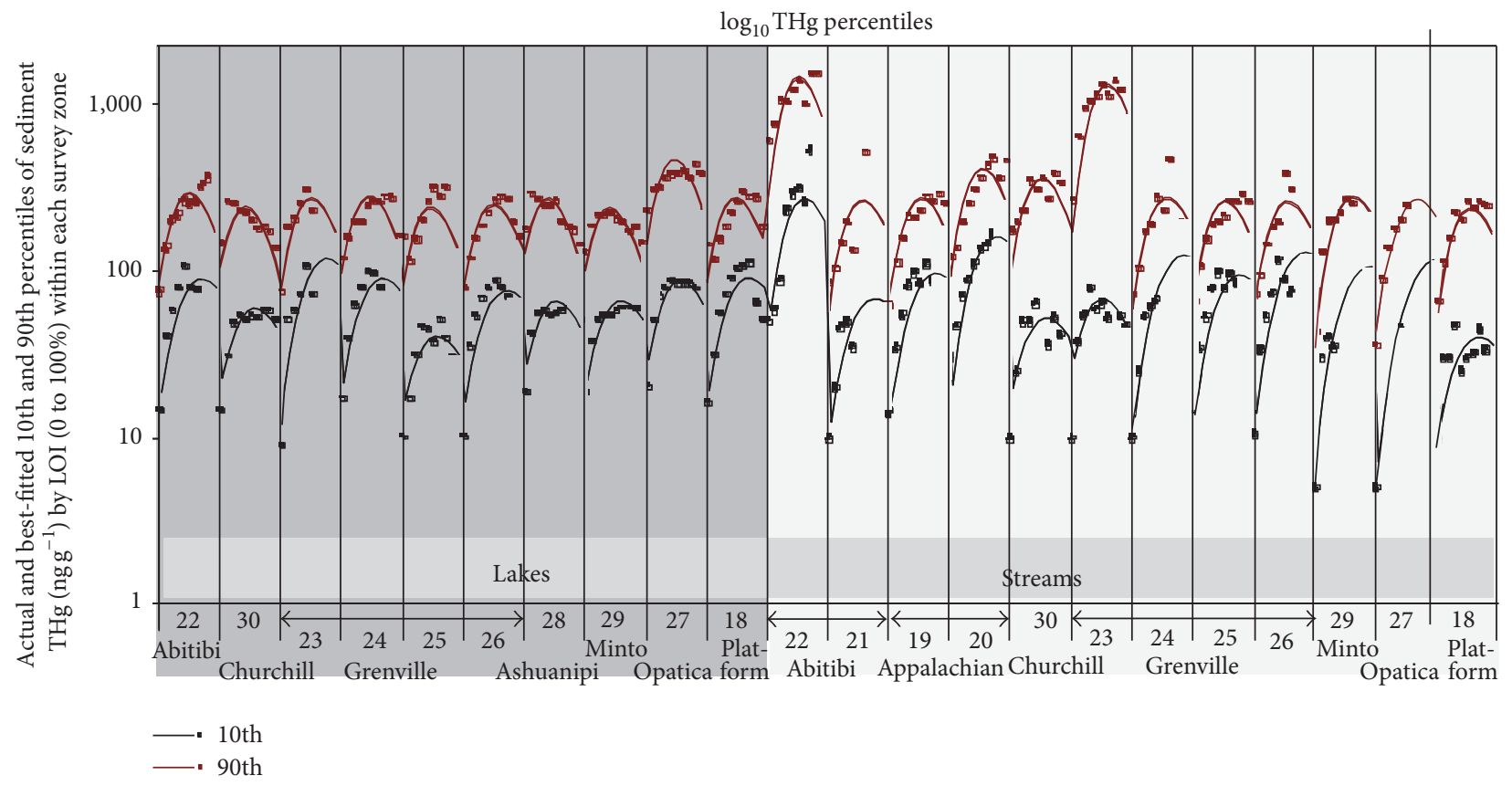

(b)

Figure 9: Plots of actual (dots) versus best-fitted 10th and 90th percentiles using (1) (lines) for lake and stream sediment $\log _{10} \mathrm{THg}\left(\mathrm{ng} \mathrm{g}^{-1}\right.$, $\log _{10}$ scale) versus $0<\mathrm{LOI}<100 \%$, by provinces/territories (a) and Quebec survey zones ((b) Figure 12).

Canada. This being so, the results suggest that lake and stream sediments become more enriched with $\mathrm{Hg}$ (i) as summers and winters become warmer, (ii) growing seasons become longer, and (iii) mean annual precipitation rates increase. The best-fitted nonlinear regression results for the percentile distributions of $\log _{10}$ THg versus sediment LOI by survey zones are generally consistent with the following observations and suggestions: (i) Atmospheric deposition to lakes is direct whereas indirect to streams. While some of the lake-deposited $\mathrm{Hg}$ volatilizes, some of it is sequestered by dissolved and particulate organic matter (DOM and POM, resp.) and by aquatic organisms. In addition, some of the DOM flocculates thereby contributing further to the organically sequestered $\mathrm{Hg}$ portion within the sediments [64]. 


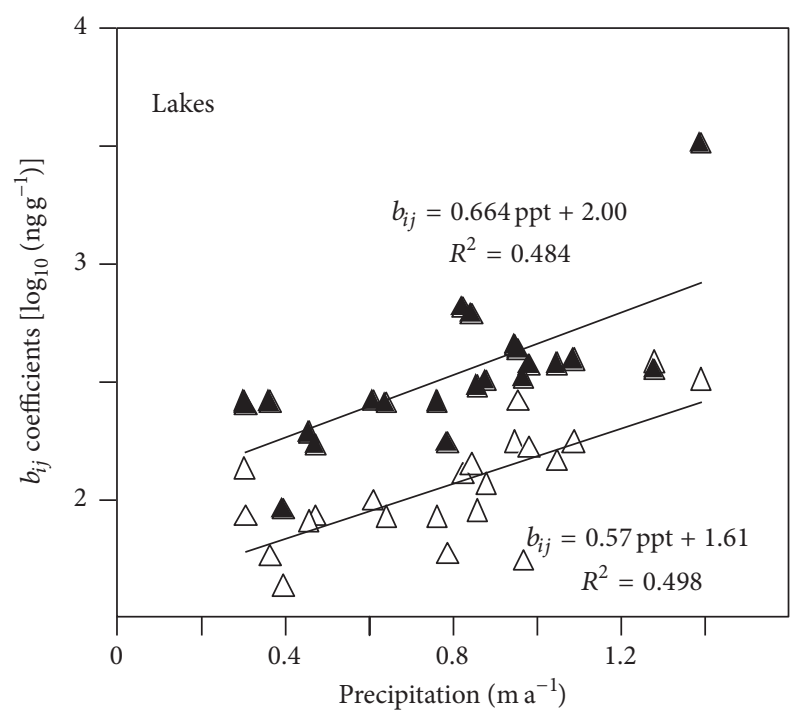

(a)

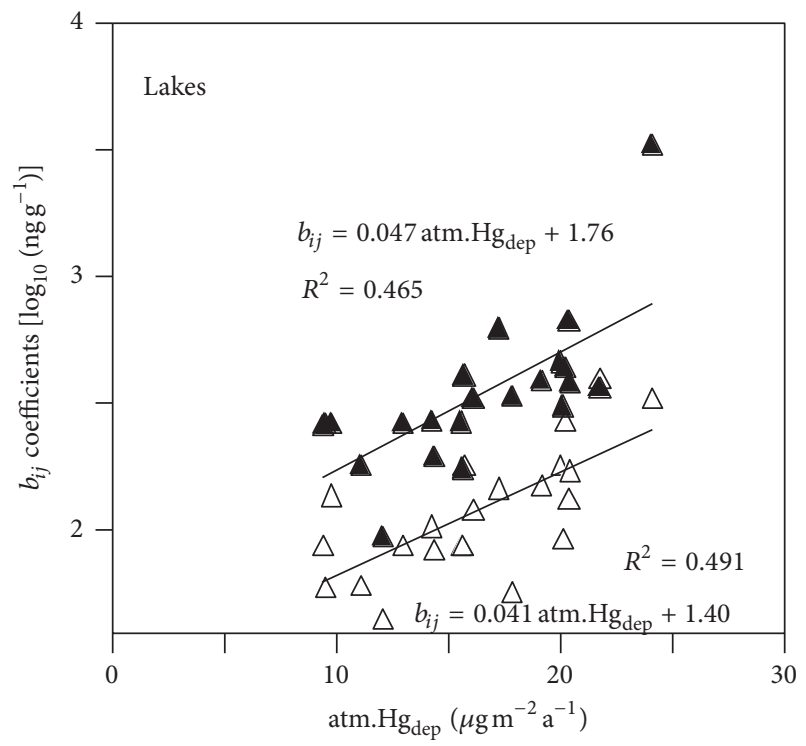

(c)

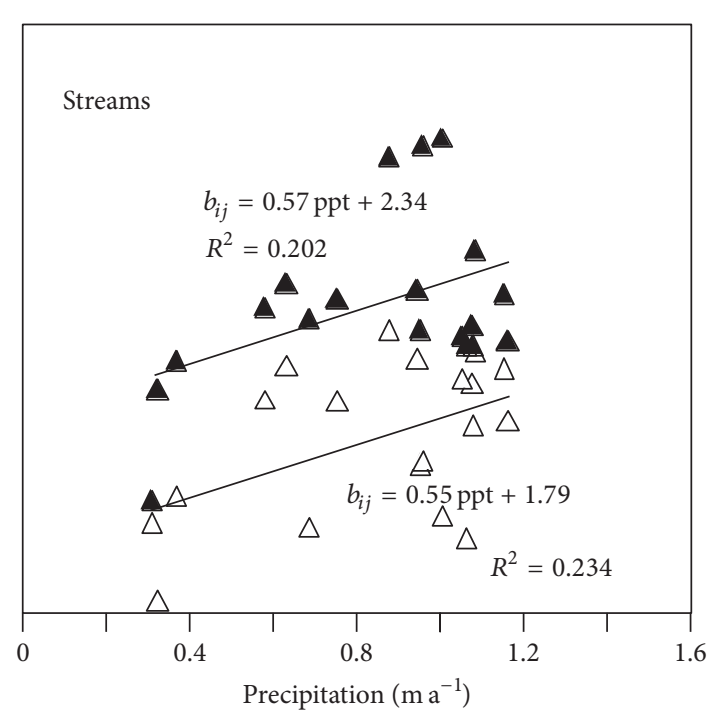

(b)

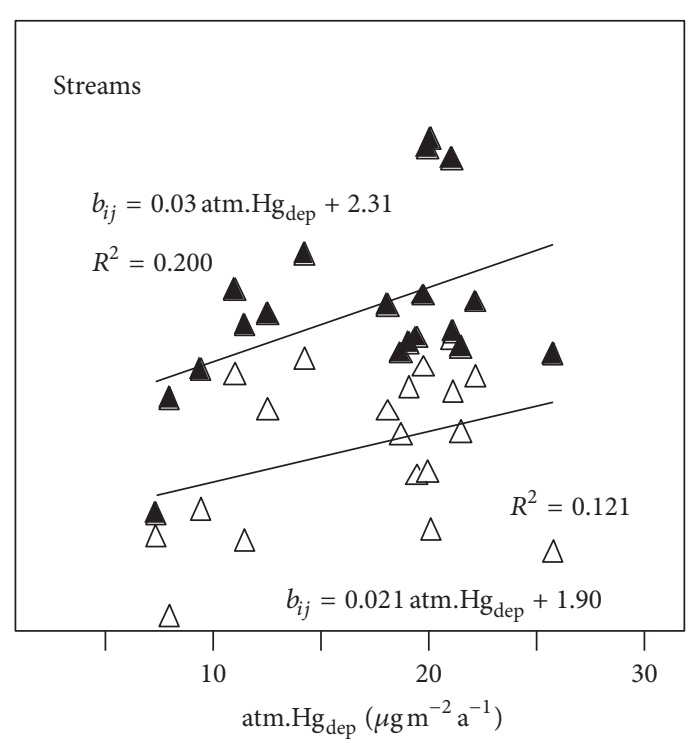

(d)

FIGURE 10: Scatterplots of best-fitted $b_{i j}$ coefficients for the 10th and 90 th $\log _{10}$ THg $\left[\log _{10}\left(\mathrm{ng} \mathrm{g}^{-1}\right)\right]$ versus (i) mean annual precipitation rate (precipitation, $\mathrm{m} \mathrm{a}^{-1}$; (a and b)) and (ii) GRAHM2005 mean annual net atmospheric Hg deposition rate (atm. $\mathrm{Hg}_{\text {dep }}, \mu \mathrm{g} \mathrm{m}{ }^{-2} \mathrm{a}^{-1}$ (c, and d)) by provinces/territories and by Quebec survey zones, based on Table 5 .

(ii) Lake catchments are generally larger than stream catchments. Therefore, lake sediment THg is more reflective of area-wide atmospheric $\mathrm{Hg}$ deposition than stream sediment THg.

(iii) Stream sediments are generally closer to local upslope Hg sources than lake sediments and are therefore less diluted.

(iv) Stream sediments are subject to frequent relocation and scouring events, with sediments varying from being coarse to fine [65-67]. In contrast, lake sedimentation is steady, cumulative, fine textured, and organically enriched [68]. In addition, lake sediments remain largely undisturbed [69].

(v) Stream sediments may lose some of the sediment THg by way of dissolved and particulate matter transport, with the finer particles generally carrying more $\mathrm{Hg}$ over larger distances than larger particles $[65,67,70$, 71].

(vi) Once entering lakes, finer particles [72] and some of the dissolved but organically bound $\mathrm{Hg}$ settles, especially after coagulation [73].

Note that all of the above results pertain to bulked lakes and stream sediment cores with no reference to sediment 

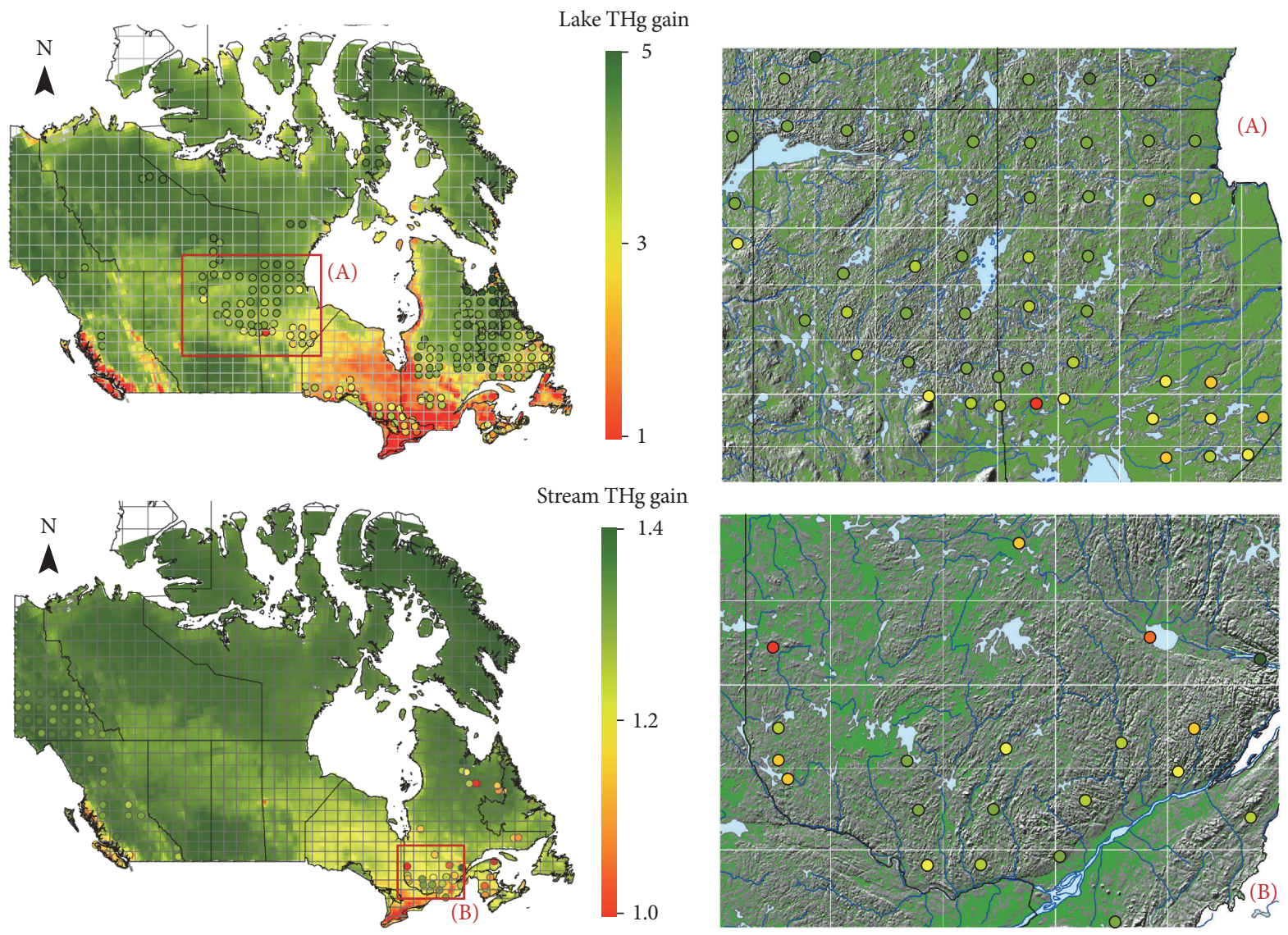

(a)

(b)

Figure 11: (a) Projected atmospherically derived gains (2) of sediment THg mapped from low (green) to high (red), based on (4), (5), and (6) estimates for LOI (\%) and annual net atmospheric $\mathrm{Hg}$ deposition as predictor variables. Overlaid dots: the corresponding $\log _{10} \mathrm{THg}_{\mathrm{gain}}$ estimates per NTS tile, using (2), (5), and (6) in combination with the mean GSC-surveyed LOI values. (b) Close-ups for the Hg gains in lake sediments across Manitoba to Alberta (top) and in stream sediments across southwestern Quebec (bottom), overlaid on a hill-shaded digital elevation grid also showing the extent of low-lying and generally wet areas next to lakes and streams (shaded green).

TABLE 5: Canadian provinces/territories: abbreviations.

\begin{tabular}{lc}
\hline Name & Abbreviation \\
\hline Alberta & AB \\
British Colombia & BC \\
Labrador & Lab \\
Manitoba & MB \\
New Brunswick & NB \\
Newfoundland \& Labrador & NL \\
Northwest Territories & NWT \\
Nova Scotia & NS \\
Nunavut & NU \\
Ontario & ON \\
Quebec & QC \\
Saskatchewan & SK \\
Yukon Territory & YT \\
\hline
\end{tabular}

depth other than lake samples being $30 \mathrm{~cm}$ deep. In detail and in contrast to LOI, THg changes strongly with increasing sediment depth, which is generally interpreted to result from (i) changes in the historical pattern of atmospheric $\mathrm{Hg}$ emission and deposition from preindustrial to modern time and (ii) changes in sedimentation processes $[20,33,74]$. As such, the best-fitted models ((4), (5), and (6)) pertain to longterm trends only. Hence, these changes could be indicative of how current to future changes in climate affect atmospheric $\mathrm{Hg}$ deposition, as summarized by the International Joint Commission, Canada and United States [75]. If so, all of this will affect not only THg and LOI, but also other correlated variables such as the bioavailability of methyl $\mathrm{Hg}$ and its trophic uptake by fish [20,74].

For detailed point-by-point examinations, one would need to increase the resolution of the analysis to address local $\mathrm{Hg}$ releasing or retaining situations as these vary upslope from each sediment sampling point. Such details would address the local variations in atmospheric $\mathrm{Hg}$ deposition and subsequent $\mathrm{Hg}$ transfer to streams and lakes. For example, (i) the dispersal of $\mathrm{Hg}$ contained in emission plumes depends on downwind air-flow pattern as affected by terrain and vegetation cover [76, 77], (ii) the transfer of POM-bound $\mathrm{Hg}$ 


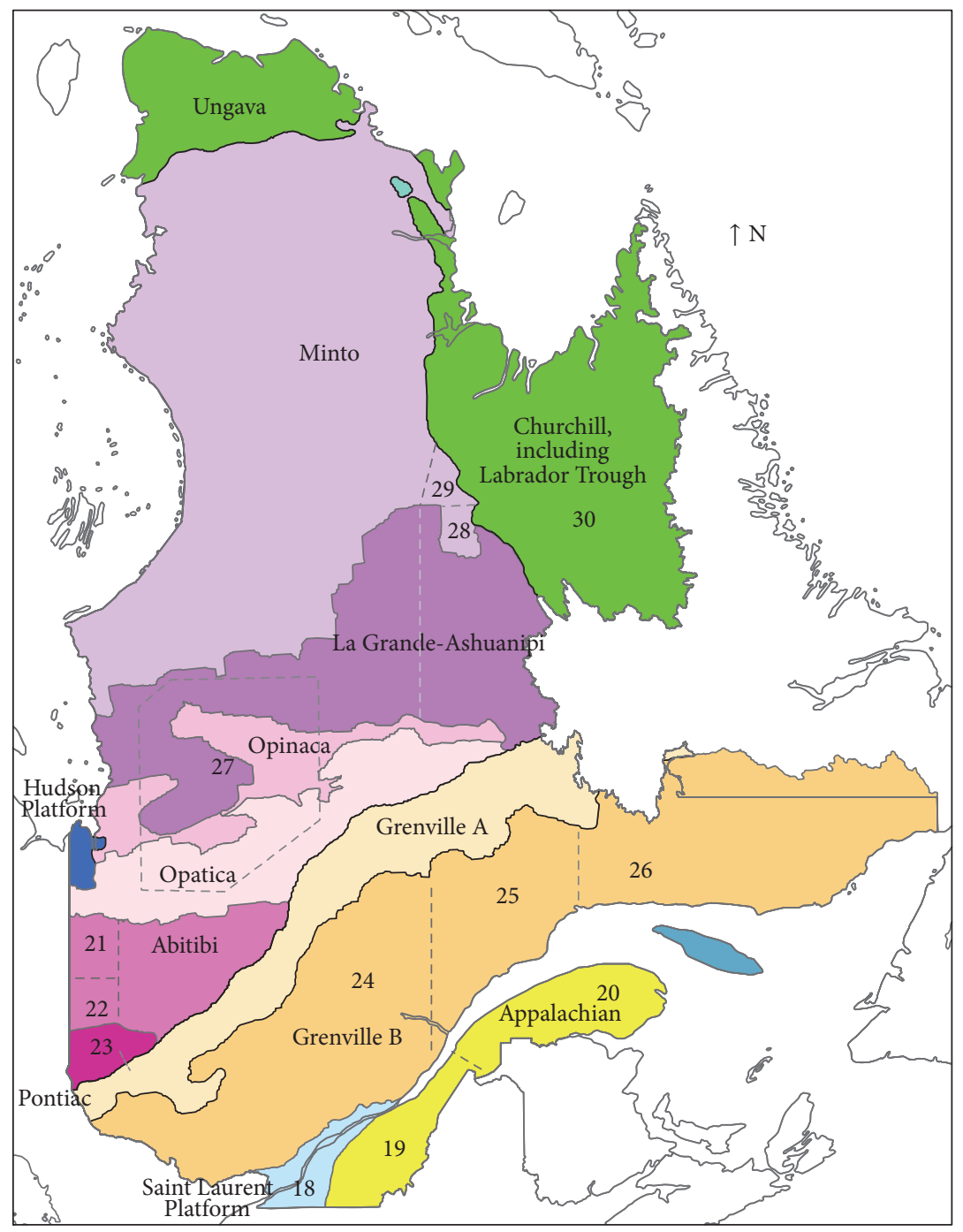

Figure 12: Sediment survey zones 19 to 30 overlaid on the geological provinces of Quebec, adapted from https://www.mern.gouv.qc.ca/ english/publications/mines/publications/geological-domains-quebec.pdf [1].

would increase with increasing slope and soil erosion, and (iii) the upslope transfer of DOM-bound Hg via run-off and stream flow would increase while POM- and mineral-bound $\mathrm{Hg}$ would decrease with increasing extent \% of upslope wet area and wetland cover [3].

While there could be differences due to region-specific biases in sediment sampling, preparation, and analysis, most of that has been addressed by employing the GSC standardized sediment surveying protocol, as described by Friske and Hornbrook [39]. In fact, the above analyses do not reveal regional biases. Instead, there is a transregional conformance pattern between the GSC data for sediment $\mathrm{THg}$ and LOI and the best-fitted results, even though the GSC data were compiled from three distinct databases (Quebec, Nova Scotia, and rest of Canada) spanning several decades.

\section{Appendix}

See Figure 12 and Table 5.

\section{Competing Interests}

The authors declare that they have no competing interests.

\section{Acknowledgments}

This work received funding from Environment Canada through the Clean Air Regulatory Agenda (CARA) Science Program, as facilitated by Dr. Heather Morrison, and was further supported through the activities of Forest Watershed Research Center of the Faculty of Forestry and Environmental Management at the University of New Brunswick in Fredericton, New Brunswick. Special thanks go to Andy Rencz for enabling and facilitating access to the GSC survey data for stream and lake sediments across Canada and to Marie-France Jones, Jae Ogilvie, and John-Paul Arp for providing technical assistance with the analyses and with manuscript production. 


\section{References}

[1] K. D. Card and A. Ciesielski, "Subdivisions of the superior province of the Canadian shield (DNAG 1)," Geoscience Canada, vol. 13, pp. 5-13, 1986.

[2] J. L. Kirk, I. Lehnherr, M. Andersson et al., "Mercury in Arctic marine ecosystems: sources, pathways and exposure," Environmental Research, vol. 119, pp. 64-87, 2012.

[3] M. Nasr, J. Ogilvie, M. Castonguay, A. Rencz, and P. A. Arp, "Total Hg concentrations in stream and lake sediments: discerning geospatial patterns and controls across Canada," Applied Geochemistry, vol. 26, no. 11, pp. 1818-1831, 2011.

[4] B. Braune, J. Chételat, M. Amyot et al., "Mercury in the marine environment of the Canadian Arctic: review of recent findings," Science of the Total Environment, vol. 509-510, pp. 67-90, 2015.

[5] J. Chételat, M. Amyot, P. Arp et al., "Mercury in freshwater ecosystems of the Canadian Arctic: recent advances on its cycling and fate," Science of the Total Environment, vol. 509-510, pp. 4166, 2015.

[6] Environment and Climate Change Canada, "Canadian mercury science assessment-summary of key results," Tech. Rep. En84130/2-2016F-PDF, Environment and Climate Change Canada, Gatineau, Canada, 2016.

[7] A. P. Clifton and C. M. G. Vivan, "Retention of mercury from an industrial source in Swansea Bay sediments," Nature, vol. 253, no. 5493, pp. 621-622, 1975.

[8] W. B. Coker, I. M. Kettles, and W. W. Shilts, "Comparison of mercury concentrations in modern lake sediments and glacial drift in the Canadian Shield in the region of Ottawa/Kingston to Georgian Bay, Ontario, Canada," Water, Air, and Soil Pollution, vol. 80, no. 1-4, pp. 1025-1029, 1995.

[9] B. E. Broster, M. L. Dickson, and M. A. Parkhill, "Comparison of humus and till as prospecting material in areas of thick overburden and multiple ice-flow events: an example from northeastern New Brunswick," Journal of Geochemical Exploration, vol. 103, no. 2-3, pp. 115-132, 2009.

[10] T. Scherbatskoy, J. B. Shanley, and G. J. Keeler, "Factors controlling mercury transport in an upland forested catchment," Water, Air, and Soil Pollution, vol. 105, no. 1-2, pp. 427-438, 1998.

[11] J. D. Demers, C. T. Driscoll, T. J. Fahey, and J. B. Yavitt, "Mercury cycling in litter and soil in different forest types in the Adirondack region, New York, USA," Ecological Applications, vol. 17, no. 5, pp. 1341-1351, 2007.

[12] S. Caron, M. Lucotte, and R. Teisserenc, "Mercury transfer from watersheds to aquatic environments following the erosion of agrarian soils: a molecular biomarker approach," Canadian Journal of Soil Science, vol. 88, no. 5, pp. 801-811, 2008.

[13] J. J. Dick, D. Tetzlaff, C. Birkel, and C. Soulsby, "Modelling landscape controls on dissolved organic carbon sources and fluxes to streams," Biogeochemistry, vol. 122, no. 2-3, pp. 361-374, 2015.

[14] A. P. Dastoor and M. Moran, "Global/Regional Atmospheric Heavy Metals Model (GRAHM2005) estimates of atmospheric mercury deposition rates at sites in northern Canada," Air Quality Research Division, Environment Canada, 2010.

[15] D. F. Grigal, "Inputs and outputs of mercury from terrestrial watersheds: a review," Environmental Reviews, vol. 10, no. 1, pp. $1-39,2002$.

[16] J. A. Ericksen, M. S. Gustin, D. E. Schorran, D. W. Johnson, S. E. Lindberg, and J. S. Coleman, "Accumulation of atmospheric mercury in forest foliage," Atmospheric Environment, vol. 37, no. 12, pp. 1613-1622, 2003.
[17] W. Machado, R. E. Santelli, D. D. Loureiro et al., "Mercury accumulation in sediments along an eutrophication gradient in Guanabara Bay, Southeast Brazil," Journal of the Brazilian Chemical Society, vol. 19, no. 3, pp. 569-575, 2008.

[18] J. Stamenkovic and M. S. Gustin, "Nonstomatal versus stomatal uptake of atmospheric mercury," Journal of Environmental Science and Technology, vol. 43, no. 5, pp. 1367-1372, 2009.

[19] P. E. Rasmussen, P. W. B. Friske, L. M. Azzaria, and R. G. Garrett, "Mercury in the Canadian environment: current research challenges," Geoscience Canada, vol. 25, no. 1, pp. 1-13, 1998.

[20] P. E. Rasmussen, D. J. Villard, H. D. Gardner, J. A. C. Fortescue, S. L. Schiff, and W. W. Shilts, "Mercury in lake sediments of the Precambrian Shield near Huntsville, Ontario, Canada," Environmental Geology, vol. 33, no. 2-3, pp. 170-182, 1998.

[21] C. Hissler and J.-L. Probst, "Impact of mercury atmospheric deposition on soils and streams in a mountainous catchment (Vosges, France) polluted by chlor-alkali industrial activity: the important trapping role of the organic matter," Science of the Total Environment, vol. 361, no. 1-3, pp. 163-178, 2006.

[22] A. Steffen, T. Douglas, M. Amyot et al., "A synthesis of atmospheric mercury depletion event chemistry in the atmosphere and snow," Atmospheric Chemistry and Physics, vol. 8, no. 6, pp. 1445-1482, 2008.

[23] D. C. G. Muir, X. Wang, F. Yang et al., "Spatial trends and historical deposition of mercury in Eastern and Northern Canada inferred from Lake Sediment Cores," Environmental Science \& Technology, vol. 43, no. 13, pp. 4802-4809, 2009.

[24] W. H. Schroeder, S. Beauchamp, G. Edwards et al., "Gaseous mercury emissions from natural sources in Canadian landscapes," Journal of Geophysical Research: Atmospheres, vol. 110, no. 18, Article ID D18302, 2005.

[25] N. J. O’Driscoll, L. Poissant, J. Canário, J. Ridal, and D. R. S. Lean, "Continuous analysis of dissolved gaseous mercury and mercury volatilization in the upper St. Lawrence river: exploring temporal relationships and UV attenuation," Environmental Science and Technology, vol. 41, no. 15, pp. 5342-5348, 2007.

[26] H. Sanei and F. Goodarzi, "Relationship between organic matter and mercury in recent lake sediment: the physical-geochemical aspects," Applied Geochemistry, vol. 21, no. 11, pp. 1900-1912, 2006.

[27] U. Skyllberg, "Competition among thiols and inorganic sulfides and polysulfides for $\mathrm{Hg}$ and $\mathrm{MeHg}$ in wetland soils and sediments under suboxic conditions: illumination of controversies and implications for $\mathrm{MeHg}$ net production," Journal of Geophysical Research: Biogeosciences, vol. 113, no. 2, Article ID G00C03, pp. 1-14, 2008.

[28] K. Xia, U. L. Skyllberg, W. F. Bleam, P. R. Bloom, E. A. Nater, and P. A. Helmke, "X-ray absorption spectroscopic evidence for the complexation of $\mathrm{Hg}(\mathrm{II})$ by reduced sulfur in soil humic substances," Environmental Science \& Technology, vol. 33, no. 2, pp. 257-261, 1999.

[29] M. Nasr and P. A. Arp, "Biomonitoring and assessing total mercury concentrations and pools in forested area," Biomonitoring, vol. 2, no. 1, pp. 47-63, 2015.

[30] H. Hintelmann and R. Harris, "Application of multiple stable mercury isotopes to determine the adsorption and desorption dynamics of $\mathrm{Hg}(\mathrm{II})$ and $\mathrm{MeHg}$ to sediments," Marine Chemistry, vol. 90, no. 1-4, pp. 165-173, 2004.

[31] X. Feng, D. Foucher, H. Hintelmann, H. Yan, T. He, and G. Qiu, "Tracing mercury contamination sources in sediments using mercury isotope compositions," Environmental Science and Technology, vol. 44, no. 9, pp. 3363-3368, 2010. 
[32] M. Nasr, Total mercury concentrations in stream and lake sediments: discerning geospatial patterns and controls across Canada [Ph.D. thesis], University of New Brunswick, New Brunswick, Canada, 2015.

[33] J. Munthe, I. Wängberg, S. Rognerud et al., "Mercury in Nordic ecosystems," IVL Report B1761, IVL Swedish Environmental Research Institute Ltd, Göteborg, Sweden, 2007.

[34] D. Obrist, A. K. Pokharel, and C. Moore, "Vertical profile measurements of soil air suggest immobilization of gaseous elemental mercury in mineral soil," Environmental Science and Technology, vol. 48, no. 4, pp. 2242-2252, 2014.

[35] M. Jiskra, J. G. Wiederhold, U. Skyllberg, R.-M. Kronberg, I. Hajdas, and R. Kretzschmar, "Mercury deposition and Reemission pathways in boreal forest soils investigated with $\mathrm{Hg}$ isotope signatures," Environmental Science and Technology, vol. 49, no. 12, pp. 7188-7196, 2015.

[36] R. Kronberg, A. Drott, M. Jiskra, J. G. Wiederhold, E. Björn, and U. Skyllberg, "Forest harvest contribution to Boreal freshwater methyl mercury load," Global Biogeochemical Cycles, vol. 30, no. 6, pp. 825-843, 2016.

[37] F. Meng, P. Arp, A. Sangster et al., "Modelling dissolved organic carbon, total and methyl mercury in Kejimkujik freshwaters," in Mercury Cycling in a Wetland Dominated Ecosystem: A Multidisciplinary Study, N. J. O’Driscoll, A. N. Rencz, and D. R. S. Lean, Eds., pp. 267-284, Society of Environmental Toxicology and Chemistry (SETAC), Pensacola, Fla, USA, 2005.

[38] Geological Survey of Canada (GSC), Natural Resources Canada (NRCAN), and Government of Canada, Canadian Geochemical Surveys, 2008, http://geochem.nrcan.gc.ca/cdogs/content/ main/home_en.htm.

[39] P. W. B. Friske and E. H. W. Hornbrook, "Canada's national geochemical reconnaissance programme," Transactions of the Institution of Mining and Metallurgy, Section B: Applied Earth Sciences, vol. 100, pp. B47-B56, 1991.

[40] R. J. Fulton, Surficial Materials of Canada. Map 1880A, Scale 1:5000000, Geological Survey of Canada, Natural Resources Canada, 1995.

[41] J. O. Wheeler, P. F. Hoffman, K. D. Card et al., Geological Map of Canada (CD-ROM) Map D1860A, Geological Survey of Canada, 1997.

[42] Ecological Stratification Working Group, A national ecological framework for Canada. Agriculture and Agri-Food Canada, Research Branch, Centre for Land and Biological Resources Research and Environment Canada, State of the Environment Directorate, Ecozone Analysis Branch, Ottawa/Hull, Report and National Map at 1:7 500000 scale; 1995.

[43] C. Daly, W. P. Gibson, G. H. Taylor, G. L. Johnson, and P. Pasteris, "A knowledge-based approach to the statistical mapping of climate," Climate Research, vol. 22, no. 2, pp. 99-113, 2002.

[44] “Canadian Digital Elevation Model," 2012, http://geogratis.gc .ca/api/en/nrcan-rncan/ess-sst/c40acfba-c722-4bel-862e-146b80be738e.html.

[45] Government of Yukon-Department of Environment GIS (ENVY GIS), 30 Meter Yukon Digital Elevation Model, 2014, http://www.env.gov.yk.ca/publications-maps/geomatics/data/ 30m_dem.php.

[46] Province of Nova Scotia, Nova Scotia’s Wetlands, 2014, http:// www.novascotia.ca/nse/wetland/.

[47] W. D. Goodfellow, "Base metal metallogeny of the Selwyn Basin, Canada," in Mineral Deposits of Canada: A Synthesis of Major
Deposit-Types, District Metallogeny, the Evolution of Geological Provinces, and Exploration Methods, W. D. Goodfellow, Ed., Special Publication no. 5, pp. 553-579, Mineral Deposits Division, Geological Association of Canada, 2007.

[48] J. Stevenson, Mercury Deposits of British Columbia, British Colombia Department of Mines, Bulletin No. 5, 1940.

[49] I. A. Paterson, "The geology and evolution of the Pinchi fault zone at Pinchi Lake, central British Columbia," Canadian Journal of Earth Sciences, vol. 14, no. 6, pp. 1324-1342, 1977.

[50] A. Plouffe, "Physical partitioning of mercury in till: an example from central British Columbia, Canada," Journal of Geochemical Exploration, vol. 59, no. 3, pp. 219-232, 1997.

[51] N. J. O’Driscoll, S. Beauchamp, S. D. Siciliano, A. N. Rencz, and D. R. Lean, "Bedrock mercury at Kejimkujik National Park," in Mercury Cycling in a Wetland-Dominated Ecosystem: A Multidisciplinary Study, N. J. O'Driscoll, A. N. Rencz, and D. R. S. Lean, Eds., vol. 37, pp. 131-195, Society of Environmental Toxicology and Chemistry (SETAC), Pensacola, Fla, USA, 2003.

[52] D. W. Davis, "U-Pb geochronology of Archean metasedimentary rocks in the Pontiac and Abitibi subprovinces, Quebec, constraints on timing, provenance and regional tectonics," Precambrian Research, vol. 115, no. 1-4, pp. 97-117, 2002.

[53] M. T. Jones and L. L. Willey, "Mont Jacques-Cartier and the Montys McGarrigle," in Eastern Alpine Guide, chapter 10, Beyond Ktaadn \& Boghaunter Books, New Salem, Mass, USA, 2012, http://easternalpine.org/eag/guide.html.

[54] J. S. A. Ramezani, M. S. Bowring, F. D. Pringle Winslow III, and E. T. Rasbury, "The Manicouagan impact melt rock: a proposed standard for the intercalibration of $\mathrm{U}-\mathrm{Pb}$ and ${ }^{40} \mathrm{Ar} /{ }^{39} \mathrm{Ar}$ isotopic systems," Geochimica et Cosmochimica Acta, vol. 69, no. 10, supplement 1, p. A321, 2005.

[55] P. Mercier-Langevin, R. Daigneault, J. Goutier, C. Dion, and P. Archer, "Geology of the Archean intrusion-hosted La-GrandeSud Au-Cu prospect, La Grande Subprovince, James Bay region, Québec," Economic Geology, vol. 107, no. 5, pp. 935-962, 2012.

[56] S. J. McCuaig and D. M. Taylor, Till Geochemistry of the Snegamook Lake Area (NTS Map Areas 13K/3, 13K/6 and 13K/11). Open File 013K/0283, 1-134, Government of Newfoundland and Labrador, Department of Natural Resources, Geological Survey, St. John's, Canada, 2005.

[57] I. M. Kettles and W. W. Shilts, "Geochemical and lithological composition of surficial sediments, southeastern Ontario," Open file 3175, Geological Survey of Canada, 1996.

[58] T. A. Al, M. I. Leybourne, A. C. Maprani et al., "Effects of acid-sulfate weathering and cyanide-containing gold tailings on the transport and fate of mercury and other metals in Gossan Creek: Murray Brook mine, New Brunswick, Canada," Applied Geochemistry, vol. 21, no. 11, pp. 1969-1985, 2006.

[59] C. F. Zhang, F.-R. Meng, J. S. Bhatti, J. A. Trofymow, and P. A. Arp, "Modeling forest leaf-litter decomposition and $\mathrm{N}$ mineralization in litterbags, placed across Canada: a 5-model comparison," Ecological Modelling, vol. 219, no. 3-4, pp. 342$360,2008$.

[60] A. C. Smith, J. S. Bhatti, H. Chen, M. E. Harmon, and P. A. Arp, "Modelling above- and below-ground mass loss and $\mathrm{N}$ dynamics in wooden dowels (LIDET) placed across North and Central America biomes at the decadal time scale," Ecological Modelling, vol. 222, no. 14, pp. 2276-2290, 2011.

[61] N. C. Kamman and D. R. Engstrom, "Historical and present fluxes of mercury to Vermont and New Hampshire lakes inferred from ${ }^{210} \mathrm{~Pb}$ dated sediment cores," Atmospheric Environment, vol. 36, no. 10, pp. 1599-1609, 2002. 
[62] E. Barrow, M. Maxwell Barrie, and P. Gachon, Climate Variability and Change in Canada, Past, Present and Future, vol. 2 of ACSD Science Assessment, Meteorological Service of Canada, Environment Canada, Toronto, Canada, 2004.

[63] B. E. Broster, A. E. Daigle, and G. M. Burtt, "Engineering properties of fine-grained estuarine sediments in the Saint John River Valley at Fredericton, New Brunswick, Canada," Atlantic Geology, vol. 49, pp. 179-193, 2013.

[64] E. Von Wachenfeldt, S. Sobek, D. Bastviken, and L. J. Tranvik, "Linking allochthonous dissolved organic matter and boreal lake sediment carbon sequestration: the role of light-mediated flocculation," Limnology and Oceanography, vol. 53, no. 6, pp. 2416-2426, 2008.

[65] J. A. Fleck, C. N. Alpers, M. Marvin-DiPasquale et al., "The effects of sediment and mercury mobilization in the south Yuba River and Humbug Ceek confluence area, Nevada County, California: concentrations, speciation, and environmental fatePart 1: field characterization," Open-File Report 2010-1325A, United States Geological Survey, Virginia, Va, USA, 2011.

[66] Y. Lin, T. Larssen, R. D. Vogt, X. Feng, and H. Zhang, "Modelling transport and transformation of mercury fractions in heavily contaminated mountain streams by coupling a GISbased hydrological model with a mercury chemistry model," Science of the Total Environment, vol. 409, no. 21, pp. 4596-4605, 2011.

[67] A. L. Riscassi and T. M. Scanlon, "Controls on stream water dissolved mercury in three mid-Appalachian forested headwater catchments," Water Resources Research, vol. 47, no. 12, Article ID W12512, 2011.

[68] J. D. Madsen, P. A. Chambers, W. F. James, E. W. Koch, and D. F. Westlake, "The interaction between water movement, sediment dynamics and submersed macrophytes," Hydrobiologia, vol. 444, pp. 71-84, 2001.

[69] R. W. Herschy, "Lake sediments," in Encyclopedia of Lakes and Reservoirs, Encyclopedia of Earth Sciences Series, pp. 458-463, 2012.

[70] M. Marvin-Dipasquale, M. A. Lutz, M. E. Brigham et al., "Mercury cycling in stream ecosystems. 2. Benthic methylmercury production and bed sediment-pore water partitioning," Environmental Science and Technology, vol. 43, no. 8, pp. 27262732, 2009.

[71] J. E. Gray, P. M. Theodorakos, E. A. Bailey, and R. R. Turner, "Distribution, speciation, and transport of mercury in streamsediment stream-water, and fish collected near abandoned mercury mines in southwestern Alaska, USA," Science of the Total Environment, vol. 260, no. 1-3, pp. 21-33, 2000.

[72] J. P. Vernet and R. L. Thomas, "The occurrence and distribution of mercury in the sediments of the Petit Lac (western Lake Geneva)," Eclogae Geologicae Helvetiae, vol. 65, pp. 307-316, 1972.

[73] F. Wu, L. Xu, H. Liao, F. Guo, X. Zhao, and J. P. Giesy, "Relationship between mercury and organic carbon in sediment cores from Lakes Qinghai and Chenghai, China," Journal of Soils and Sediments, vol. 13, no. 6, pp. 1084-1092, 2013.

[74] A. L. M. Ethier, A. M. Scheuhammer, J. M. Blais et al., "Mercury empirical relationships in sediments from three Ontario lakes," Science of the Total Environment, vol. 408, no. 9, pp. 2087-2095, 2010.

[75] International Joint Commission, Canada and United States, Atmospheric Deposition of Mercury in the Great Lakes Basin, Cat. No.: E95-2/21-2015E-PDF, 2015.
[76] M. S. Landis, J. V. Ryan, A. F. H. Ter Schure, and D. Laudal, "Behavior of mercury emissions from a commercial coalfired power plant: the relationship between stack speciation and near-field plume measurements," Environmental Science \& Technology, vol. 48, no. 22, pp. 13540-13548, 2014.

[77] C. P.-A. Bourque and P. A. Arp, "Simulating sulfur dioxide plume dispersion and subsequent deposition downwind from a stationary point source: a model," Environmental Pollution, vol. 91, no. 3, pp. 363-380, 1996. 

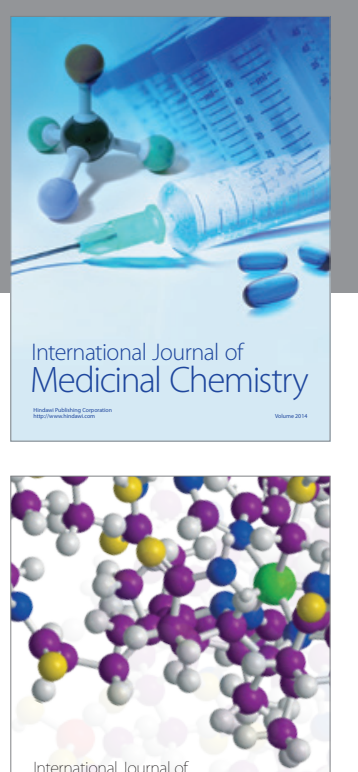

Carbohydrate Chemistry

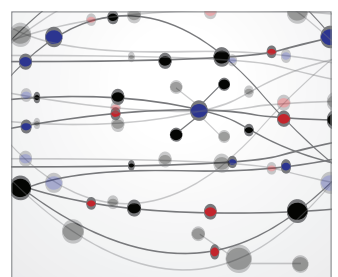

The Scientific World Journal
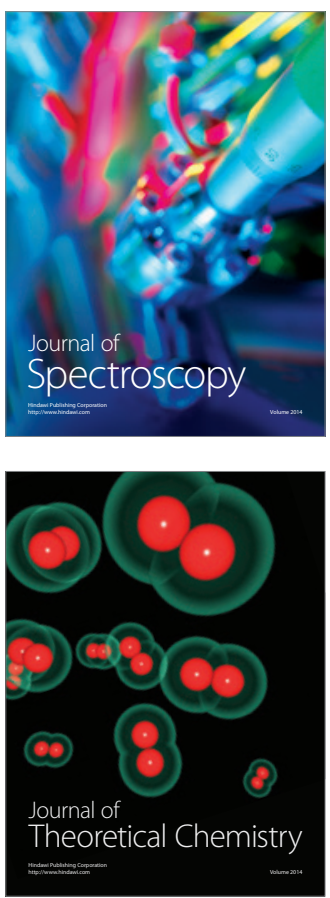
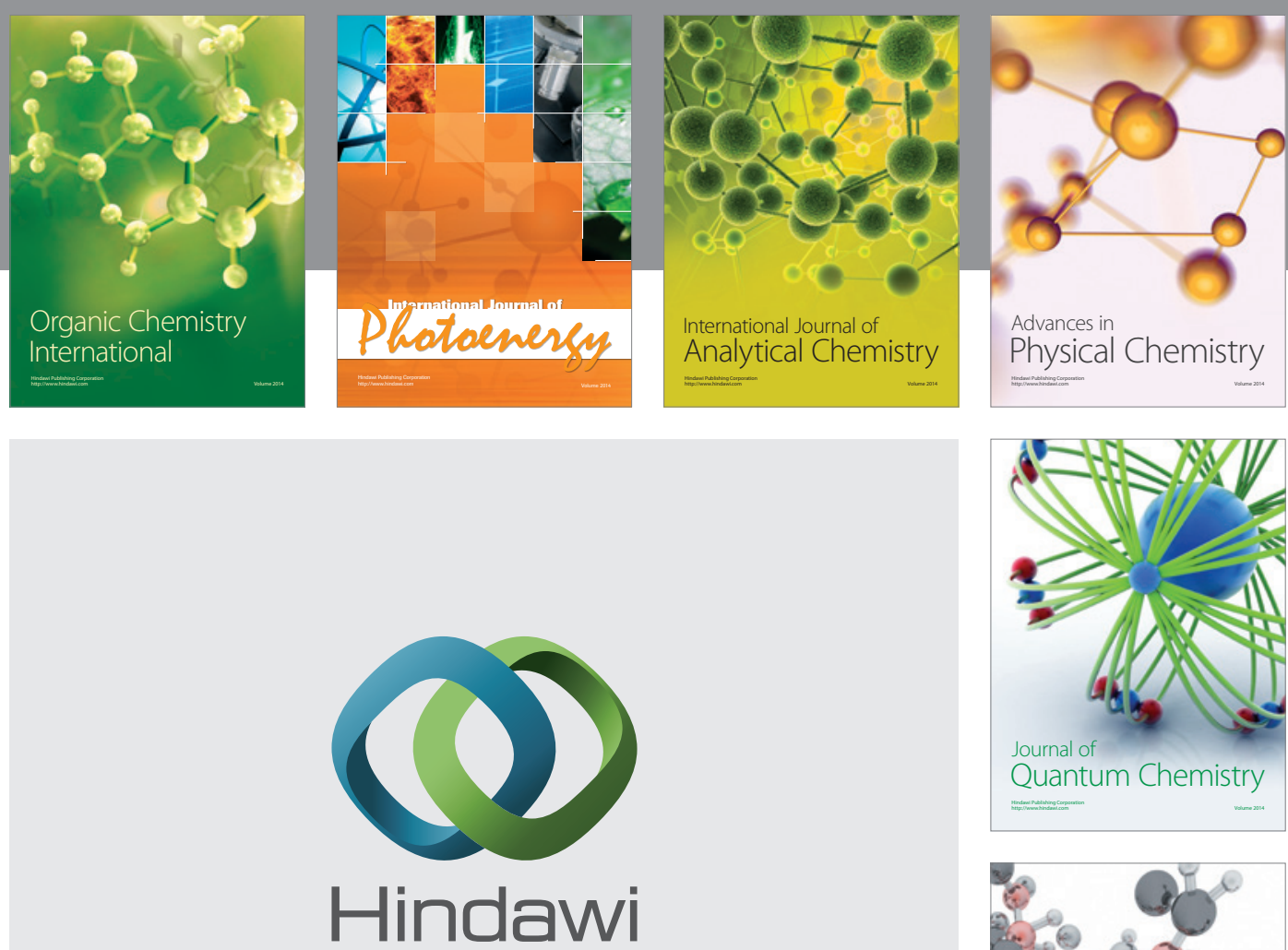

Submit your manuscripts at

https://www.hindawi.com

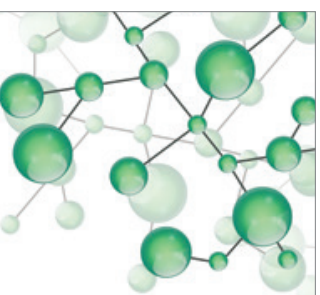

International Journal of

Inorganic Chemistry
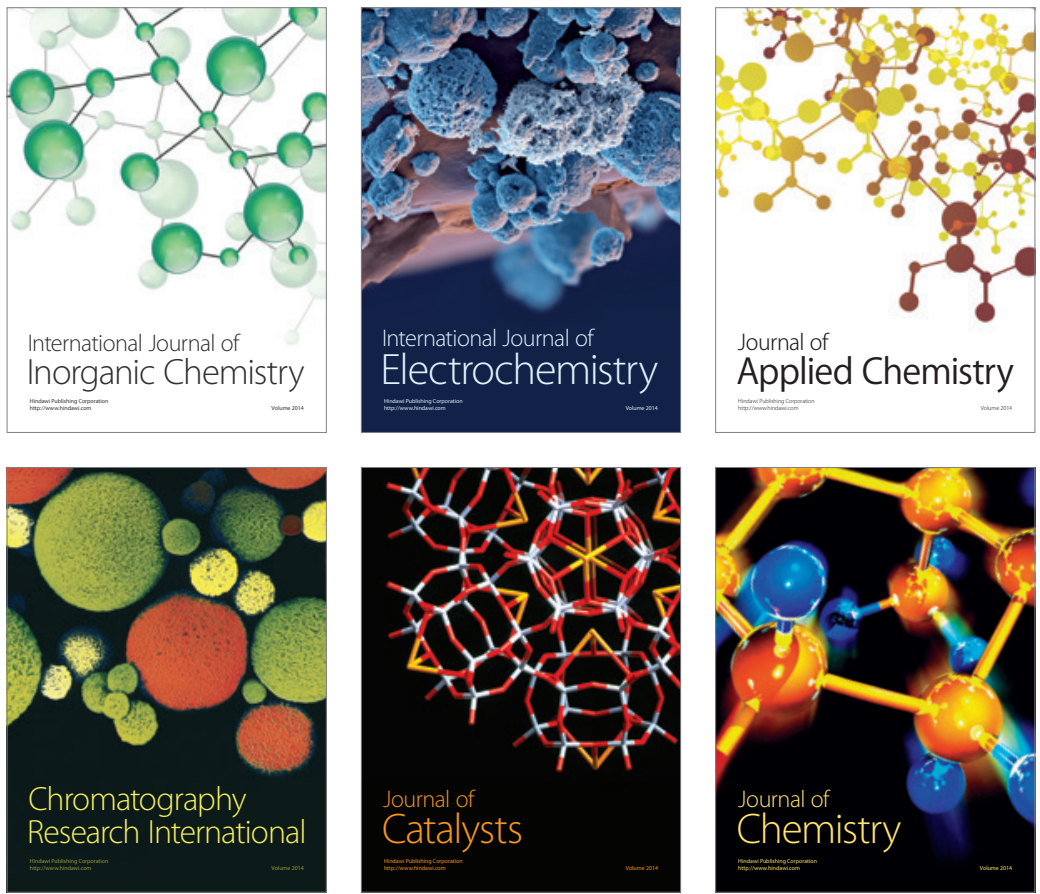

Journal of

Applied Chemistry
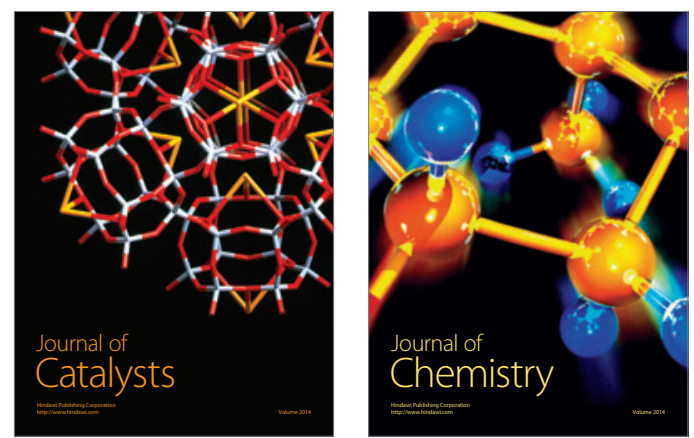
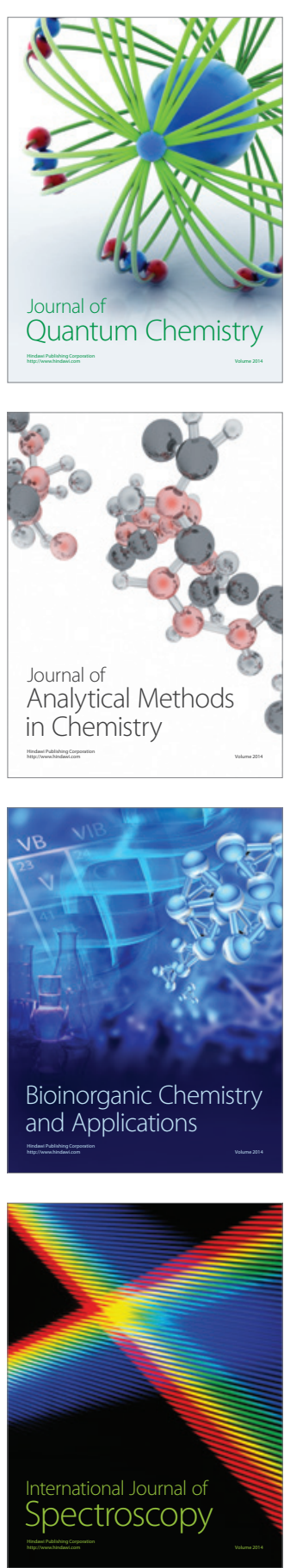